\title{
Örgüt Temelli Özsaygı ile Algılanan İstihdam Edilebilirlik Arasındaki İlişkide Cinsiyetin Düzenleyici Etkisi ve Bir Uygulama
}

\author{
DOI: 10.26466/opus.706649 \\ * \\ Kenan Orçanl1 * \\ * Dr. Öğr. Üyesi, Toros Üniversitesi, İiBSF, İşletme, Mersin \\ E-Posta: kenanorcanli@gmail.com \\ ORCID: $\underline{0000-0001-5716-4004}$
}

\begin{abstract}
Öz
Örgütsel davranış literatüründe gizil değişkenler arasındaki ilişkilerin araştırılması oldukça önemlidir ve her disiplinde olduğu gibi bu şekilde yapılan araştırmalar gelecekteki araştırmalar için bir temel teşkil etmektedir. Örgüt temelli özsaygı ile algılanan istihdam edilebilirlik kavramları da bu kapsamda incelenmesi gereken önemli gizil değişkenlerdir. Yapılan çalışmanın amacı, örgüt temelli özsaygı ile algılanan istihdam edilebilirlik kavramları arasındaki ilişkide cinsiyetin düzenleyici rolünü araştırmaktır. Yapılan çalışmada kullanılan veriler, Ankara ve Mersin illerinde bulunan 5 devlet üniversitesinde görev yapan 372 akademisyene Temmuz-Kasım 2019 döneminde web tabanl olarak uygulanan $i k i$ adet ölçek ile toplanmış ve analizler, SPSS ve AMOS paket programları ile $R$ ve Python programlama dillerinde yapılmıştır. Çalışmanın sonunda, örgüt temelli özsaygı ile algılanan istihdam edilebilirlik kavramları arasında pozitif ve aynı yönlü bir ilişkinin olduğu ve çalışanların cinsiyetinin örgüt temelli özsaygı ile algılanan istihdam edilebilirlik arasındaki ilişkide düzenleyici bir rol üstlendiği tespit edilmiştir. Bu şekilde ortaya konan sonucun, hem örgütsel davranış literatürüne katkı sağlayacă̆ı hem de işletmelerde yönetici pozisyonunda bulunan kişiler ile bir işyerinde ücret karşılı̆̆l çalışanlara meslek yaşantılarında faydalı olacağı değerlendirilmektedir.
\end{abstract}

Anahtar Kelimeler: Örgüt temelli özsaygı, Algılanan istihdam edilebilirlik, Cinsiyet 


\title{
The Moderating Effect of Gender in Relationship between Organization-Based Self-Esteem on and Self-Perceived Employment, and an Application
}

\begin{abstract}
In the organizational behavior literature, it is very important to investigate the relationships between latent variables and, as in all disciplines, such research is the basis for future research. The concepts of self-perceived employment and organization-based self-esteem are also important latent variables that should be examined in this context. The aim of study is to examine the moderator effect of the gender factor in the relationship between organization-based self-esteem and self-perceived employment. The data used in the study was gathered with two scales applied based on web in July-November in 2019 to 372 academics working in 5 universities located in Ankara and Mersin provinces and the SPSS and AMOS package programs and $R$ and Python programming languages were used in the analysis. At the end of the study, it was found that there was a positive and same-way relationship between organization-based self-esteem and self-perceived employment, and that the gender of the employees played a moderating role in the relationship between organization-based self-esteem and self-perceived employment. It is evaluated that the result presented in this way both will contribute to the organizational behavior literature and will be beneficial for people who are in managerial positions in businesses and those who work in a workplace for a fee
\end{abstract}

Keywords: Organization-based self-esteem, Self-perceived employment, Gender 


\section{Giriş}

İnsanoğlunun tüm davranışlarının nedeni motivasyondur. Nitekim motivasyonun kökeninin de Latince "harekete geçirme" anlamı taşıyan "move$\mathrm{re}^{\prime \prime}$ kelimesi olduğu ifade edilmektedir. Örgüt ortamında motivasyon, sadece bireysel amaçlar açısından değil, örgütsel amaçlar açısından da ele alınmalıdır. Bu kapsamda motive etmek, örgütsel ve bireysel amaçları gerçekleştirecek şekilde iş ortamı yaratmak, böylece çalışanı çalışmaya istekli hale getirerek harekete geçmesini sağlamak şeklinde tanımlanabilir (Ergeneli, 2017, s.194). İnsanı harekete geçiren, diğer bir anlatımla motive eden, en önemli unsur ise ihtiyaçtır. İhtiyaç, "gereksinim, güçlü istek, yoksulluk, yokluk" olarak tanımlanmaktadır (https://sozluk.gov.tr/). Dolayısıyla insanlar, hissettikleri eksiklikleri gidermek için harekete geçer.

İnsan, sosyal bir varlıktır. Bu kapsamda değerlendirildiğinde insanın hem bireysel hem de toplumsal ihtiyaçlarından bahsedilebilir. Nitekim Maslow (1943), insanın ihtiyaçlarını önem sırasına göre sıralamış, bu ihtiyaçların ilk üçünün bireysel, kalan ikisinin ise hem toplumsal hem de bireysel gelişim ile ilgili olduğunu belirtmiştir. Bireysel ihtiyaçlar; fizyolojik, güvenlik ve ait olma şeklinde ifade edilmekte ve "temel ihtiyaçlar" olarak adlandırılmaktadır. Bu ihtiyaçlar giderildiği takdirde kişi bir üst seviye olan "sayg1 ihtiyacı" ve "kendini gerçekleştirme" ihtiyacını gidermek konusunda girişimlerde bulunmaktadır. Maslow'a göre tatmin edilmiş davranışların, kişinin davranışı üzerinde etkisi yoktur. Ancak bu husus temel ihtiyaçlar için geçerlidir. İnsanın kendisine saygı duyması ve başkalarından saygı görmesi ile kendini gerçekleştirmesi tatmin edildikçe, daha çok tatmin edilme arzusu uyandırmaktadır.

Örgütte çalışan bir kişinin temel ihtiyaçlarını karşıladığı değerlendirilebilir. Çünkü ücret, çalışma koşulları, iş güvencesi, sigorta ve emeklilik, arkadaşlık ilişkileri gibi temel ihtiyaçların karşılanmadığı bir ortamda kişinin uzun süre çalışmaya devam etmesini beklemek çok gerçekçi bir yaklaşım olmayacaktır. Temel ihtiyaçları karşılanan çalışanlar, gerek yükselme gerek statü ve tanınma gibi imkanlardan dolayı örgüt dışında çalıştı̆̆ı örgütün bir üyesi olmaktan, örgüt içinde de gerek başarmak gerek takdir edilmek gibi işyerindeki rolünden dolayı kendini değerli hissetmek ister. Kendisini geliştirme ve potansiyelini sergileme imkanı bulan çalışan da örgütte kalmak için gayret gösterir. 
Yukarıda verilen Maslow'un motivasyon kuramı kapsamında cinsiyetin örgüt temelli özsaygı ile algılanan istihdam edilebilirlik arasında düzenleyici bir rol oynayabileceği değerlendirilmiş ve bu kapsamda yapılan çalışmada, cinsiyetin örgüt temelli özsaygı ile algılanan istihdam edilebilirlik arasinda düzenleyici bir rolünün olup olmadığı araştırılmıştır.

\section{Kavramsal Çerçeve}

Bu çalışmada iki değişken üzerinde durulmuştur. İlki “örgüt temelli özsayg1" diğeri ise "algilanan istihdam edilebilirlik"tir. "Örgüt temelli özsaygı" Organization-Based Self-Esteem (OBSE) kavramının Türkçeye çevrilmiş halidir. "Self-Perceived Employability" (SPE) kavramı ise Türkçeye "kendi kendini istihdam etme", "algilanabilir istihdam edilebilirlik" veya "kendi kendine algılanan istihdam edilebilirlik" olarak tercüme edilebilir. Bu çalı̧̧mada "algılanan istihdam edilebilirlik" kavramının kullanılması tercih edilmiştir.

\section{Örgüt Temelli Özsayg1}

"Öz" kelimesi "kendine, kendi kendini" anlamlarında birleşik kelimeler türeten bir sözdür (TDK). Bu anlamda "özsayg1"yı "kişinin kendi kendisine saygisı" olarak ifade etmek uygun olacaktır.

Sui ve Wang (2014) örgütle ve yöneticiyle olan ilişkilerde, çalışanların tepkilerinin altında özsaygı mekanizmalarının yattığını ileri sürmüştür (Keleş, 2015: s.10). Özsaygı, bir bireyin kendi yeterliliklerini genel olarak değerlendirmesini ifade eder. $\mathrm{Bu}$ anlamda insanların kendileri hakkında kişisel bir değerlendirmesidir. Bireyin kendisini yeterli, ihtiyaçlarını tatmin edici bir birey olarak görme derecesini yansıtır. Yüksek düzeyde özsaygısı olan bir kişide kişisel yeterlilik duygusu ve geçmişte ihtiyacını tatmin etmiş olma duygusu söz konusudur. Bu nedenle, genel özsaygisı yüksek insanların, "ben diğer insanlarla eşit değerdeyim" ve "kendimden memnunum" gibi kabulleri vardır (Pierce ve Gardner, 2004, s.592).

Özsaygının kaynakları iktidar, önem, erdem ve yeterliliktir (Mruk, 2006, s.75). Gardner ve arkadaşlarına (2018: s.351) göre özsaygının gelişmesi genetik bir temele sahip olmasının yanı sıra yaşam deneyimleriyle şekillenen evrensel bir güdü gibi görünmektedir (Başgüt, 2019, s.82). 
Literatürde kişilerin genel özsaygısına odaklanan çalışmaları yaygın olarak görmek mümkün iken 1990'lı yıllardan itibaren "örgüt temelli özsaygı" üzerine de yoğunlaşıldığı görülmektedir. Özsaygının hiyerarşik birçok yönlü bir olay olduğu fikrinin ortaya çıkması ve özsaygının, bireyin kendisinin ne kadar yetenekli, önemli ve değerli olduğuna inandığını göstermesi örgüt temelli özsaygı kavramını ortaya çıkarmıştır (Pierce ve Gardner, 2004, s.593).

Örgüt temelli özsaygı, örgüt ortamında çeşitli rollerde bulunan insanların, örgütün bir üyesi olarak, kendisini önemli ve değerli bulma gibi ihtiyaçlarını karşıladığına dair inanç düzeyidir (Pierce vd., 1989; Pierce ve Gardner, 2004: s.593). Diğer bir anlatımla çalışanların bünyesinde bulunduğu örgütteki rolleri çerçevesinde kendi ihtiyaçlarını tatmin edebildiklerine dair inançlarının derecesidir (Akalın, 2006, s.52; Erden, 2011, s.29; Keleş, 2015, s.6). Kısaca örgüt temelli özsaygı, çalışanların örgütün üyesi olarak kendi değerleri ve yetkinlikleriyle ilgili inançlarını ifade etmektedir (Bowling vd., 2010).

Örgüt temelli özsaygr; "iş tatmini, örgütsel bağlllık, motivasyon, örgütsel vatandaşlık davranışı, iş performansı ve işten ayrılma niyeti gibi örgütle ilgili tutum ve davranışlar" ile ilgilidir (Pierce ve Gardner, 2004, s.591).

Örgüt temelli özsaygı algısı yüksek çalışanlar örgütte önemli, yetkin ve istihdam edilebilecek yetenekte olduklarını düşünürler. Ayrıca bu kişiler, örgütte itibar gördüklerini düşünür, her yerde bir fark yarattılarına ve örgütün önemli bir parçası olduklarına inanırlar (Pierce ve Gardner, 2004, s.593). Yüksek örgüt temelli özsaygısı olanlar, bir örgüt üyesi olarak kişisel yeterlilik duygusuna ve geçmişte örgütsel rollerden kaynaklanan önemli bir iş yapma, çevre tarafından takdir edilme, yararlı olma gibi gereksinimlerinin doyurulduğu duygusuna sahiptir. Dolayısıyla yüksek örgüt temelli özsaygiya sahip olan çalışanlar, kendilerini çalıştıkları örgütte önemli, anlamlı, etkili ve değerli olarak algılar (Yıldırım, 2003, s.381).

Örgüt temelli özsaygı halen çalışılan örgütte şekillenen bir özsaygı boyutu iken, genel özsaygı daha durağan bir yapıdadır. Genel özsaygının insan yaşamındaki kökeni çocukluğa kadar varan uzun bir geçmişe dayanır. Bowling ve arkadaşları (2010)'nın yaptıkları çalışmada, örgüt temelli özsaygının işle ilgili değişkenlerle ilişkisinin, genel özsaygının işle ilgili değişkenlerle olan ilişkisinden daha güçlü olduğu sonucuna ulaşılmıştır. Ayrıca ör- 
güt temelli özsaygının, genel özsaygı ve işle ilgili kriterler arasındaki ilişkilere aracllık ettiği tespit edilmiştir.

Pierce ve Gardner, (2004: s.594) karmaşık iş tasarımlarının, rutin olmayan teknolojilerin, organik tasarımın ve katılımcı sosyal sistemlerin daha yüksek özsaygı düzeyine yol açacağını belirtmiştir. Çünkü bunlar çalışanlara kendisini örgütsel rollere uygunluk ve kendini ifade etme konusunda daha büyük firsatlar sunacaktır. Bir organizasyondaki başarılı deneyimler, bireyin organizasyon temelli özsaygısını artırırken, başarısız deneyimler kişinin bu başarısızlı̆̆ kendisine bağlamasından dolayı özsaygının azalmasına yol açacaktır (Pierce ve Gardner, 2004, s.594).

Örgüt temelli özsaygı kavramını literatüre katan Pierce ve arkadaşları (1989) yapmış oldukları çalışmalarında, özsaygı kavramını işletmeler açısından ele almışlar ve kavrama ilişkin bazı öncüller belirlemişlerdir. Pierce ve arkadaşları (1989, s.628-629)'nın yapmış oldukları çalışmada ifade edilen öncülleri aşağıdaki gibi belirtmek mümkündür (Keleş, 2015, s.7; Başgüt, 2019, s.86).

- Diğerlerinin (yönetici, çalışma arkadaşları gibi) çalışanın performansı hakkındaki inancı ve beklentisi,

- Yönetimsel tutum ve davranışlar ile şekli,

- Yapılan işin özelliği ve işin zorluk derecesi.

Artan örgüt temelli özsaygı düzeyi ile birlikte çalışanın olumlu yönde değişen davranış ve tutumları sayesinde, örgütlerin hedeflerine daha kolay ulaşacağ1 düşünülmektedir (Başgüt, 2019, s.85). Şöyle ki; Korman (1976)'a göre bireyler tutum ve davranışlarını özsaygı düzeylerini sürdürecek biçimde geliştirir. Bu kuramsal ilkeye göre, çalışma ortamında yüksek özsaygıya sahip bireylerin iş doyumları ve verimleri de yüksek olacaktır. Diğer yandan, düşük özsaygılı bireylerin, işe yönelik olumsuz tutum sergilemeleri ve verimsiz iş davranışlarında bulunmaları beklenebilir (Yıldırım, 2003, s.380). Bu kapsamda yapılan çalışmalarda örgüt temelli özsaygının çalışanın motivasyonunu, tutumlarını ve işle ilgili davranışlarını etkilediği kabul edilmektedir (Başgüt, 2019: s.90; Akalın, 2006: s.58). Nitekim Başgüt (2019, s.91), yaptığı çalışmada, örgüt temelli özsaygı ile performans, iş tatmini ve örgütsel vatandaşlık arasında pozitif ve anlamlı bir ilişki tespit etmiştir. Ayrıca yüksek düzeydeki örgüt temelli özsayg hem iş performansını (Keleş, 2015, s.9) hem de yaşam doyumunu (Keleş, 2015: s.49; Özçelik Bozkurt ve Özkoç, 2019) olumlu düzeyde etkilemektedir. 
İş ve örgütsel deneyimler etrafında oluşmuş bir bireyin özsaygısı, çalışanların motivasyonu, işe bağlı tutum ve davranışlarını belirlemede önemli bir rol oynar (Pierce ve Gardner, 2004). Pierce ve Gardner (2004, s.606-609) içsel motivasyon, işle ilgili tutumlar, örgütsel değişime uyum, işte kalma, etik davranış niyeti, geribildirim arama davranışı, kariyer seviyesi çıktıları ve mentorluğu örgüt temelli özsaygının sonuçları olarak belirtmiştir. Bu kapsamda yüksek özsaygının çoğunlukla olumlu sonuçlar ihtiva ettiği söylenebilir.

Mruk, (2006, s.6) ise yüksek özsaygının, bazı istenmeyen davranış biçimleriyle, örneğin bencillikle, narsisizmle ve hatta şiddetle ilişkili görülebileceğini ifade etmiştir. Örgüt temelli özsaygı kavramının negatif ilişki içinde olduğu kavramlar; geri çekilme davranışı, rol belirsizliği, rol çatışması ve nevrotiklik, olumsuz iş davranışları ve işten ayrılma niyeti şeklinde belirlenmiştir.

\section{Algılanan İstihdam Edilebilirlik}

İstihdam edilebilirlik, insanların istedikleri türden iş bulmak ve çalışmak için gerekli becerilere ve diğer özelliklere sahip olmalarıyla ilgilidir (Fugate vd., 2004, s.16; Rothwell ve Arnold, 2007, s.25). İstihdam kavramı geçmişte aynı organizasyonda uzun yıllar çalışabilmeyi çağrıştırırken, günümüzde artan küreselleşme ve hızla gelişen bilgi teknoloji ortamına paralel olarak değişim göstermiştir. Söz konusu ortam bireyleri daha dinamik davranmaya sevk etmektedir. Artık bireyler aynı organizasyonda uzun yıllar çalışmak bir yana, aynı kariyerde devam etme imkânı bile bulamamaktadır. İş güvencesizliği bu anlamda çalışanların ve adayların önünde devamlı tehdit olarak durmaktadır. Kısaca tek bir işte uzun yıllar çalışma ve çalıştırma anlayışından uzaklaşılmıştır. Örgütler de çalışanlarını uzun süre istihdam etme gereği duymamaktadır. Bu kapsamda değerlendirildiğinde istihdam edilebilirlik, çalışanların iş güvencesi ile ilgili önemli bir kavramdır.

Ömür boyu aynı organizasyonda çalışmak artık pek mümkün olmadığı için iş güvencesinin farklı şekillerde korunması ihtiyacı belirmiştir. İşgücü piyasasında da "ömür boyu istihdam" yerine "ömür boyu işe alınabilirlik" kavramı kullanılır hale gelmiştir (Forrier ve Sels, 2003, s.102). Bireylerin tahmin edilmesi güç, hareketli ve daha değişken işgücü piyasası koşullarıyla başa çıkmalarının bir yolu "istihdam edilebilirlik" olmaktadır (Berntson 
vd., 2006, s.224). Çalışanların, işgücü piyasasının değişken dinamikleri içerisinde farklı işler ve örgütler arası geçiş yapabilmesi için, kendilerini "istihdam edilebilir" kılmaya yönelik sürekli öğrenme ve geliştirmeye yönelik faaliyetlerde bulunması gerekmektedir (Gerçek ve Elmas Atay, 2017, s.92). $\mathrm{Bu}$ durumda bireyler mevcut pozisyonların korumak hatta terfi etmek veya farklı bir işe girmek için devamlı kendisini sorgulamalı ve potansiyelini koruyup geliştirmelidir. Bu değerlendirmeler kendi kendini istihdam etme kavramının önemine ve gerekliliğine işaret etmektedir. Bireyin işgücü piyasasında gerçekte ne kadar ilgi göreceğinden çok, kişinin bu konuya ilişkin kendi düşünceleri önem kazanmaktadır (Gerçek ve Elmas Atay, 2017, s.93).

Gerçek ve Atay (2017, s.92)'a göre, "istihdam edilebilirliğe yönelik ilk çalışmalar 1950'li yıllarda başlamış, işsizlerin tam istihdama dâhil edilmesine odaklanılmıştır. 1980'lerde istihdam edilebilirlik, örgütsel düzeyde ele alınmıştır. 1990'lardan itibaren istihdam edilebilirliğin iş güvencesizliğine bir alternatif olabileceği" düşünülmüştür.

Bu çerçevede istihdam edilebilirlik, bireyin iç veya dış işgücü piyasasında bir işte kalma yeteneği olarak tanımlanmaktadır. Fugate ve arkadaşları (2004, s.1)'na göre istihdam edilebilirlik, kariyer kimliği, kişisel uyarlanabilirlik, sosyal ve beşerî sermaye olmak üzere üç boyuttan oluşan, işe özgü aktif uyarlanabilirliği ifade eder.

Forrier ve arkadaşları (2015) tarafından yapılan çalışma, farklı istihdam edilebilirlik kavramlarını, parçalanmışlıktan kurtarıp birleştirmeyi hedeflemiştir. Yazarlar, istihdam edilebilirliği "bir bireyin iç ve/veya dış işgücü piyasasında iş bulma şansı" olarak tanımlamaktadır.

Berntson ve arkadaşları (2006, s.225)'na göre istihdam edilebilirlik, "nesnel ve algılanan istihdam olmak üzere ikiye ayrılmaktadır. Nesnel istihdam edilebilirlik, bireyin eğitim durumu ya da işgücü piyasasındaki pozisyonu gibi somut göstergelere ilişkindir. Algılanan istihdam edilebilirlik ise, bireyin ayn işletmede farklı bir işe veya farklı işletmelerde yeni bir işe girip giremeyeceğine ilişkin kişinin kendi değerlendirmeleri" ile ilgili bir kavramdır (Gerçek ve Elmas Atay, 2017, s.93). Benzer şekilde Rothwell ve Arnold (2007), algılanan istihdam edilebilirliği, içsel ve dışsal olmak üzere iki şekilde ele almıştır. Forrier ve arkadaşları (2015, s.58)'na göre algılanan içsel istihdam edilebilirlik, "bireyin çalıştığı örgütteki istihdam edilebilirliğine ilişkin algılarını yansıtırken, algılanan dışsal istihdam edilebilirlik ise bireyin 
farklı bir örgütte istihdam edilme olasıllğına ilişkin düşünceleri" ni ifade etmektedir (Gerçek ve Elmas Atay, 2017, s.94).

Algılanan istihdam edilebilirlik, kişinin gelecekteki iş dünyasında, özellikle kısa periyotlu iş değiştirme kapasitesinin mevcut bir değerlendirmesidir (Rothwell ve Arnold, 2007, s.25). Çalışanın kendi yaptığ bu değerlendirmede geleceğe yönelik beklentiler odak noktasındadır. Kişinin yeni bir iş bulma girişiminin ne ölçüde kolay olacağıyla ilgili düşünceleri (Rothwell ve Arnold, 2007), niteliklerine uygun bir iş bulabilme konusunda algılama kabiliyeti (Rothwell vd., 2008) şeklinde ifade edilmektedir (Özçelik Bozkurt ve Özkoç, 2019, s.266). Birey açısından istihdam edilebilirlik anlayışı, çalışanların kendi kariyer gelişimlerini yönetmesi ve iş güvencelerini koruma yönünde kendilerini geliştirmeleri gerektiğini öne sürmektedir. İşveren açısından bakıldığında işveren, ihtiyaç duyulan niteliklerin değerlendirilmesi ve geliştirilmesi için çalışanlara gerekli bilgiyi, zamanı, kaynağı ve fırsatları sunmalıdır (Gerçek ve Elmas Atay, 2017, s.93).

Wittekind ve arkadaşları (2009, s.566)'nın yapmış oldukları araştırma, "eğitim, kariyer ve beceri gelişimine destek, mevcut işle ilgili becerilerin seviyesi ve iş değiştirmeye istekli olmak", algılanan istihdam edilebilirliğin öncülleridir. İstihdam edilebilirlik, ayrıca özyeterlik, özsaygı ve özgüven gibi kişisel algilardan da etkilenmektedir (Sumanasiri vd., 2016, s.128). Andrew ve Higson (2008), istihdam edilebilirlik için transfer edilebilir bazı beceri ve yetkinliklerden bahsetmiştir. Bunlar; profesyonellik, güvenilirlik, belirsizlikle mücadele yeteneği, baskı altında çalışabilme yeteneği, stratejik olarak düşünme ve plan yapabilme yeteneği, diğerleriyle iletişim ve bir ağ kurabilme yeteneği, yazılı ve sözlü iletişim becerilerine sahip olma, yaratıclık ve öz güven, öz yönetim ve zaman yönetimi becerileri ve öğrenme ve sorumluluk almaya istekliliktir (Aybas ve Kırbaşlar, 2014, s.356).

Birey açısından istihdam edilebilirlik algısı oluşmasını sağlayan faktörler; "sahip olduğu bilgi ve beceri, bu varlıkları kullanma biçimi ve işverenlere sunma biçimi ve iş aradığı ortam koşullarının durumuna" bağlıdır. Böylece sadece bilgi ve beceri değil, bunları yansıtma biçiminin de önemli olduğu görülmektedir (Erdem vd. 2016, s.774). İstihdam edilebilirliği etkileyen faktörleri tanımlamak, istihdam edilebilirliği arttırabilmek, geliştirebilmek açsından önem taşımaktadır. Aybas ve Kırbaşlar (2014, s.353)'ın yaptığı çalışma sonuçlarına göre, hırs ve iç kontrol odaklılığın istihdam edilebilirlik üzerinde olumlu yönde etkisi olduğu tespit edilmiştir. 
Bireylerin "istihdam edilebilir" olarak nitelendirilebilmeleri için, hali hazırda çalışıyor olma koşuluna gerek duyulmamaktadır (Gerçek ve Elmas Atay, 2017, s.92). Öğrencilerin, yani gelecekte çalışan olacakların da istihdam edilebilir olmayla ilgili algıları vardır.

Birçoklarının istihdam denince "bireyin istihdam edilebilirlik becerileri ve nitelikleri" terimini kullanmalarını 'dar' bir kullanım olarak gören McQuaid ve Lindsay (2005, s.197); konunun arz ve talep yönüne vurgu yaparak bireysel faktörler, kişisel koşullar ve dış faktörler etrafında inşa edilen istihdam edilebilirliği analiz etmek için geniş bir çerçeve kullanmıştır.

Çalışanların istihdam edilebilir olabilmesi için sadece kendi branşlarına özgü mesleki uzmanlıkları yeterli değildir. Bunun yanında "çeşitli ve transfer edilebilir becerilere ve niteliklere" ihtiyaç duyulmaktadır. Bilginin yoğunlaşması, küreselleşme ve hizmet sektöründeki büyümeden kaynaklanan çalışma yaşamının doğasındaki değişim, bu gelişimin ana nedenini oluşturmaktadır (Heijde ve Heijden, 2005, s.143 Akt. Erdem vd. 2016, s.774).

Algılanan istihdamı daha yüksek olan bireyler işyerindeki durumu daha iyi değerlendirebilecek ve sonuçta daha sağlıklı ve iyi varlık gösterebilecektir (Berntson ve Marklund, 2007, s.279). Algılanan istihdam edilebilirlik düzeyi yüksek olan kişi kendini güvende hisseder ve çevresel koşullara karşı bağımsız hareket edebilir (Özçelik Bozkurt ve Özkoç, 2019, s.267).

\section{Örgüt Temelli Özsaygı ile Algılanan İstihdam Edilebilirlik Arasındaki İlişki ve Cinsiyetin Bu İlişkiye Etkisi}

Bireylerin üst düzey örgüt temelli özsaygıya sahip olması çalıştığı kurumun bir parçası olarak kişisel yeterliliğe sahip olduğunu ve geçmişe yönelik olarak sahip olduğu roller neticesinde ihtiyaçlarının tatmin edildiğini göstermektedir. Kişilerin örgüt içinde kendilerine verilen görevle ilgili olarak yeterlilik duygusunda olması örgütsel temelli özsaygının bir sonucudur (Yeşiltaş, 2014, s.127). Pierce ve arkadaşları (1989)'na göre, örgüt temelli özsaygısı yüksek olan kişi örgütün bir üyesi olarak kişisel yeterlilik hissedecek ve dolayısıyla örgütteki görevlerinden tatmin olacaktır, çalışan, kendini örgüt içinde verimli, anlamll, etkili ve değerli bir birey olarak görecektir (Keleş, 2015, s.6). Algılanan istihdam edilebilirlik de bireyin kendine yeni, eşit düzeyde (De Cuyper vd., 2011, s.1487) veya daha iyi bir iş bulma olasılığı konusundaki düşüncesidir (Bernston vd., 2006). 
Bir organizasyonda çalışan bireyin bu örgütten kaynaklanan durumlardan temel alan özsaygısı yüksek olunca onun istihdam edilebilirlikle ilgili algılamalarının da olumlu olması, istihdam konusunda kendine güvenmesi beklenmektedir. Dolayısıyla örgüt temelli özsayg1 ile algılanan istihdam edilebilirlik arasında anlamlı bir ilişki olduğu söylenebilir. Bu kapsamda kurulan hipotez şu şekilde ifade edilmiştir:

- $\quad H_{1}$ : Örgüt temelli özsaygı ile algılanan istihdam edilebilirlik arasmda anlaml ve ayn yönlü bir ilişki vardır.

Aybas ve Kırbaşlar (2014, s.360) tarafindan yapılan araştırmada katılımcı öğrencilerin kendilerine ilişkin istihdam edilebilirlik algılamaları, cinsiyete göre farklılık göstermektedir. Erkek öğrencilerin kız öğrencilere göre kendilerine ilişkin olan inanç algılamaları daha yüksektir. Diğer bir ifade ile kız öğrenciler, kendilerini erkek öğrencilere göre daha az istihdam edilebilir bulmaktadırlar. Erdem ve arkadaşları (2016, s.779)'nın çalışanlar üzerinde yaptıkları araştırmada algılanan istihdam edilebilirliğin cinsiyete göre anlamlı bir farklılık göstermediği belirlenmiştir.

McColl-Kennedy ve Anderson, (2005) tarafindan Avustralya'da bir farmakoloji şirketinde yapılan araştırmada, astlar arasında en yüksek özsaygı düzeyinin, yöneticinin kadın, astın erkek olduğu durumlarda yaşandığı tespit edilmiştir (Akalın, 2006, s.63). Erden (2011, s.56) tarafından yapılan araştırmada kadınların örgüt temelli özsaygı ortalamalarının erkeklerin ortalamasından daha yüksek olduğu görülmüştür. Keleş (2015, s.33-34) tarafından yapılan araştırmada yine kadınların ortalamaları, erkeklerin ortalamasından daha yüksek olduğu bulunmuştur. Başgüt, (2019, s.136) tarafında yapılan araştırmada tıbbi satış mümessili çalışanların örgüt temelli özsaygı düzeyinin cinsiyet durumuna göre anlamlı bir şekilde farklılaştığı ve kadın çalışanların örgüt temelli özsaygı düzeyinin erkeklere oranla daha yüksek olduğu tespit edilmiştir. Bunların yanında; Bowling ve arkadaşları (2010, s.614) tarafından yapılan çalışmada ise cinsiyetin örgüt temelli özsayg1 ile bir ilişkisi tespit edilememiştir (Başgüt, 2019, s.97). Literatürde yer alan ve yukarıda ifade edilen çalışmalar ışığında oluşturulan hipotez şu şekilde ifade edilebilir: 
- $\quad \mathrm{H}_{2}$ : Örgüt temelli özsayg ile algılanan istihdam edilebilirlik arasındaki ilişkide cinsiyetin düzenleyici etkisi vardır.

Çalışmada kullanılan örgüt temelli özsaygının algılanan istihdam edilebilirlik üzerinde cinsiyetin düzenleyici etkisini gösteren araştırma modeli Şekil-1'de sunulmuştur. Araştırma modelinde örgüt temelli özsaygı değişkenin algılanan istihdam edilebilirlik değişkenin üzerindeki direkt ve bu ilişkide cinsiyet değişkenin düzenleyici etkisi gösterilmiştir.

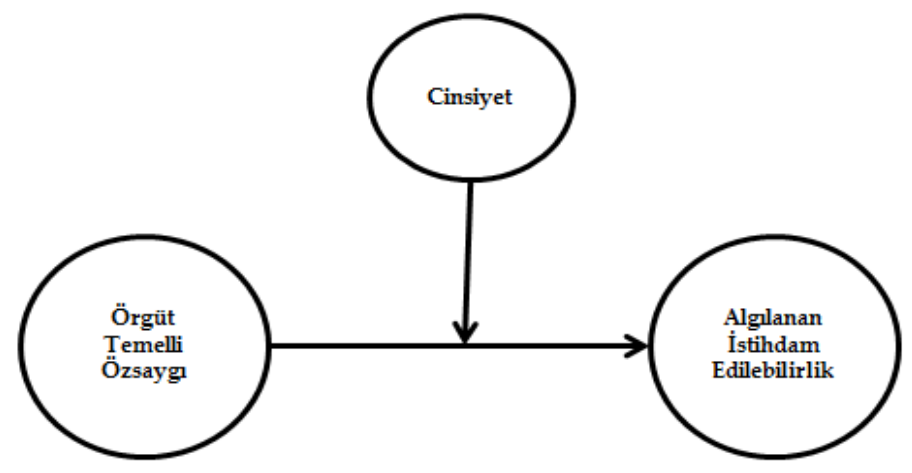

Şekil 1. Araştırma Modeli

\section{Ampirik Bir Araştırma}

Yapılan araştırmanın uygulama bölümünde; çalışmanın amacı, çalışmanın yapıldığı yer, çalışmanın anakütlesi ve örneklemi, çalışmada kullanılan yöntem, yapılan analizlerde kullanılan verilerin toplanmasinda kullanılan alg1lanan istihdam edilebilirlik ölçeğinin açıklayıcı ve doğrulayıcı faktör analizleri ve güvenirlik analizi ile örgüt temelli özsaygi ölçeğinin doğrulayıc faktör analizi, değişkenler arasındaki ilişkideki düzenleyici etkinin incelendiği regresyon analizi ve bu analizler sonucunda elde edilen bulgular ile ilgili bilgilere yer verilmiştir.

\section{Çalışmanın Amacı}

Bu çalışma, örgüt temelli özsaygı ile algılanan istihdam edilebilirlik kavramları arasındaki ilişkide cinsiyet değişkeninin düzenleyici etkisinin olup olmadığının araştırılarak sonuçlarının ortaya konması amacıyla yapılmıştır. 
Yazında örgüt temelli özsaygı ile algılanan istihdam edilebilirlik kavramları arasındaki ilişkide aracılık etkisini inceleyen bazı araştırmalara rastlanmasına rağmen, örgüt temelli özsaygı ile algılanan istihdam edilebilirlik kavramları arasındaki ilişkide cinsiyetin düzenleyicilik etkisini inceleyen herhangi bir çalışmaya rastlanmamıştır. İfade edilen iki değişken arasındaki ilişkide cinsiyetin düzenleyici etkisinin incelenmesi ilk olması nedeniyle önem arz etmektedir ve yapılan çalışmanın yazına katkı sağlayacağı değerlendirilmektedir.

\section{Çalışmanın Yapıldığı Yer, Anakütle ve Örneklem}

Çalışmada kullanılan veriler (birincil veri), Temmuz-Kasım 2019 döneminde Ankara ve Mersin illerinde bulunan beş adet devlet üniversitesinde görev yapan akademisyene uygulanan bir anket (web tabanlı olarak google formlarda oluşturulan iki ölçek) ile toplanmıştır. Çalışmanın yapıldığı dönemde beş devlet üniversitesinde 567 kişi çalışmaktaydı. Dolayısıyla çalışmanın ana kütlesini bu çalışan grup oluşturmaktadır. Bu kapsamda örneklem büyüklügü ise (1) no'lu formülden yararlanılarak hesaplanmıştır (Eygü ve Güllüce, 2017).

$$
n=\frac{N p q Z^{2}}{(N-1) d^{2}+p q Z^{2}}
$$

Formül-1'de n: Örneklem sayısı, N: Anakütle sayısı, p: İncelenecek olayın görülüşs sıklığı (olasılığı), q: İncelenecek olayın görülmeyiş sıklığı (1-p), $Z$ : Belirli serbestlik derecesinde ve saptanan yanılma düzeyinde $t$ tablosunda bulunan teorik değer $(\%(1-\alpha)$ düzeyinde $\mathrm{Z}$ test değeri, $\alpha=$ Önem düzeyi), d: Olayın görülüşs sıklığına göre yapılmak istenen \pm sapma (hata (tolerans) payı) olarak simgelenmiştir. Bu formül ana kütle sayısının bilinmesi halinde kullanılmaktadır. Çalışmada büyük örnekle çalışmak için ankete katılanların oranları 0.5 olarak alınmış, $\% 5$ önem düzeyinde $\% 5$ hata payı ile ana kütleyi temsil edecek örnek büyüklüğ̈̈;

$$
n=\frac{(567 * 0.5 * 0.5 * 1.96 * 1.96)=544.54}{(566 * 0.05 * 0.05)=1.415+(0.5 * 0.5 * 1.96 * 1.96)=0.96}=229
$$


olarak bulunmuştur. Araştırmada hedeflenen minimum örnek büyüklüğü 229 kişidir.

Araştırmada örnekleme yöntemi olarak tesadüfi olmayan örnekleme yöntemlerinden kolayda örnekleme yöntemi seçilmiş ve bu kapsamda 400 adet anket sahaya sürülmüştür. Anket uygulaması yapıldıktan sonra eksik ve boş anketler ayıklanmış ve geriye 372 anket kalmıştır. Doldurulan ve değerlendirmeye alınan anket sayısı çalışma için gereken 229 katılımcıdan fazladır.

Analizlerde algılanan istihdam edilebilirlik ölçeğinin açıklayıcı faktör analizinde 116 kişilik (birinci örneklem) ve her iki ölçeğin doğrulayıcı faktör analizi ile cinsiyetin düzenleyici etkisinin incelendiği regresyon analizinde ise 256 kişilik (ikinci örneklem) grubun verdiği yanıtlar kullanılmıştır. 256 kişilik (ikinci örneklem) gruba ait demografik bilgilerin yer aldığı çizelge Tablo 1'de sunulmuştur.

Tablo 1. İkinci Örneklemin Demografik Bilgileri (Örneklem sayısı 256 kişi)

\begin{tabular}{|c|c|c|c|c|c|c|c|}
\hline Değişken & & $\mathrm{f}$ & $\%$ & Değişkeı & & $\mathrm{f}$ & $\%$ \\
\hline \multirow{3}{*}{ Cinsiyet } & & & & \multirow{3}{*}{ Statï } & Öğr.Üyesi & 56 & 22 \\
\hline & Kadın & 104 & 41 & & Öğr.Gör. & 88 & 34 \\
\hline & & & & & Arş.Gör. & 112 & 44 \\
\hline \multirow{4}{*}{ Eğitim } & Lisans & & & \multirow{4}{*}{ Yaş } & 20 ve aşağ1 & 0 & 0 \\
\hline & Y I icance & & & & $21-40$ & 130 & 51 \\
\hline & Y.Lisans & 74 & 29 & & $41-60$ & 80 & 31 \\
\hline & Doktora & 66 & 26 & & 61 ve yukarı & 46 & 18 \\
\hline
\end{tabular}

\section{Çalışmada Kullanılan Yöntem}

Yapılan çalışmada kullanılan verilerin toplanmasında Örgüt Temelli Özsaygı Ölçeği ve Algılanan İstihdam Edilebilirlik Ölçeği olmak üzere iki adet ölçek kullanılmıştır.

Örgüt Temelli Özsaygı Ölçeği: Pierce, Gardner, Cumming ve Dunham (1989) tarafından tek boyutlu olarak oluşturulmuş ve Türkçe çevirisi ile geçerlik ve güvenirlikleri ise Akalın (2006) tarafından yapılmıştır. Türkçe'ye uyarlanan ölçek, orijinal halinde olduğu gibi yine tek faktörlü olmak üzere 10 sorudan oluşmaktadır. Ölçeğin iç tutarlılık katsayısı, Akalın (2006) tarafından 0.93 olarak bulunmuştur. Ayrıca Türkiye'de Erden (2011) tarafından ayrı bir çalışmada ölçek kullanılmış ve soruların şıkları Akalın (2006)'da 7'li 
Likert tipli ile Erden (2011)'in çalışmasında 5'li Likert tipli olarak kullanılmıştır. Bu çalışmada ise Erden (2011) tarafından kullanım şekli benimsenmiştir.

Algılanan İstihdam Edilebilirlik Ölçeği: ise Rothwell ve Arnold (2007) tarafından oluşturulmuş, geçerlik ve güvenirlik çalışması yapılmıştır. Söz konusu ölçeğin Türkçe'ye uyarlaması ile geçerlik ve güvenirlik çalışması, Gerçek ve Elmas Atay (2017) tarafindan yapılmıştır.

Rothwell ve Arnold (2007) tarafindan ilk olarak oluşturulmuş ölçekte yapı hedef davranışı ölçmek maksadıyla iki faktörlü olarak tasarlanmış, içsel istihdam edilebilirlik için 8 soru ve dişsal istihdam edilebilirlik için 8 soru olmak üzere toplam 16 adet soru kullanılmışken, Gerçek ve Elmas Atay (2017) tarafından Türkçe'ye uyarlaması esnasında hedef davranışın ölçülmesinde ölçekte yapının yine iki faktörlü olmasının ve 10 adet sorunun yer almasının (içsel istihdam edilebilirlik için 4 soru ve dişsal istihdam edilebilirlik için 6 soru) uygun olacağı değerlendirilmiştir. Ayrıca Firat ve arkadaşları (2019) tarafından Türkiye'de döküm sanayinde ve Bekmezci ve arkadaşları (2020) tarafından Ankara/Türkiye'de devlet ve vakıf üniversitelerinde olmak üzere iki ayrı anakütlede yapılan iki çalışmada ise söz konusu ölçek ile ilgili geçerlik ve güvenirlik çalışmalarında yapılan analizler sonucunda ölçeğin tek boyutta toplandığ 1 ortaya konmuştur. Ancak Firat ve arkadaşları (2019) ve Bekmezci ve arkadaşları (2020) tarafindan yapılan çalışmalarda birer anakütle ile açıklayıcı ve doğrulayıcı faktör analizleri yapılmış ve bu analizler sonunda elde edilen uyum iyiliği değerlerine göre değerlendirme yapılmıştır. Belirtilen nedenden dolayı algılanan istihdam edilebilirlik ölçeği ile bu çalışmada bir defa daha ancak iki anakütle ile açıklayıcı ve doğrulayıcı faktör analizlerinin yapılmasına ihtiyaç duyulmuş̧tur.

Rothwell ve Arnold (2007) tarafından yapılan çalışmada ölçeğin Cronbach alpha değerleri; içsel istihdam edilebilirlik değeri 0.72, dışsal istihdam edilebilirlik değeri 0.79 ve ölçeğin toplam değeri 0.83; Gerçek ve Elmas Atay (2017) tarafından yapılan çalışmada ölçeğin Cronbach alpha değerleri; içsel istihdam edilebilirlik değeri 0.812 , dışsal istihdam edilebilirlik değeri 0.845 ve ölçeğin toplam değeri 0.88 , uyum iyiliği değerleri olarak RMSEA: 0.088 olarak; Fırat ve arkadaşları (2019) tarafından yapılan çalışmada ölçeğin Cronbach alpha değeri 0.904, uyum iyiliği değerleri olarak CFI: 0.968, RMR (SMSR): 0.027, RFI: 0.924 ve NFI: 0.94 olarak ve Bekmezci ve arkadaşları 
(2020) tarafından yapılan çalışma ölçeğin Cronbach alpha değerinin 0.70 değerinin üzerinde olduğu ve uyum iyiliği değerlerinden $S M S R$ (RMR): 0.06 olarak bulunmuştur.

\section{Çalışmada Kullanılan Verilerin Çok Değişkenli Normal Dağılımlarının Kontrolü}

Çalışmada yapılan regresyon analizi ile doğrulayıcı ve açılayıcı faktör analizlerinde iki grup veri kullanılmıştır. Bu iki grup veri, algılanan istihdam edilebilirlik ölçeğinin açıklayıc faktör analizinde 116 kişilik örneklem ve her iki ölçeğin doğrulayıc faktör analizi ile cinsiyetin düzenleyici etkisinin incelendiği regresyon analizinde ise 256 kişilik örneklem gruplarıdır. Bu örneklem grupları analizlerde kullanılmadan önce mutlaka değişkenlerin çok değişkenli normal dağılım ile ortalama değerlerinin tek değişkenli normal dağılımının kontrolü yapılması gerekir. Bu kapsamda $\mathrm{R}$ programlama dilinde yapılan Henze-Zirkler çok değişkenli normal dağılım testlerinin sonuçları Tablo 2'de ve ölçeklerin ortalama değerleri ile ilgili Python programlama dilinde yapılan Anderson-Darling normal dağılım testleri ile elde edilen sonuçlar ise Tablo $3^{\prime}$ te verilmiştir.

Tablo 2. Çalışmada Kullanılan Ölçeklerin Birinci ve İkinci Grup Gözlemlerinin Çok Değişkenli Normal Dağılımının Kontrolü ile Ilgili Yapılan Testler (R Programlama Dilinde)

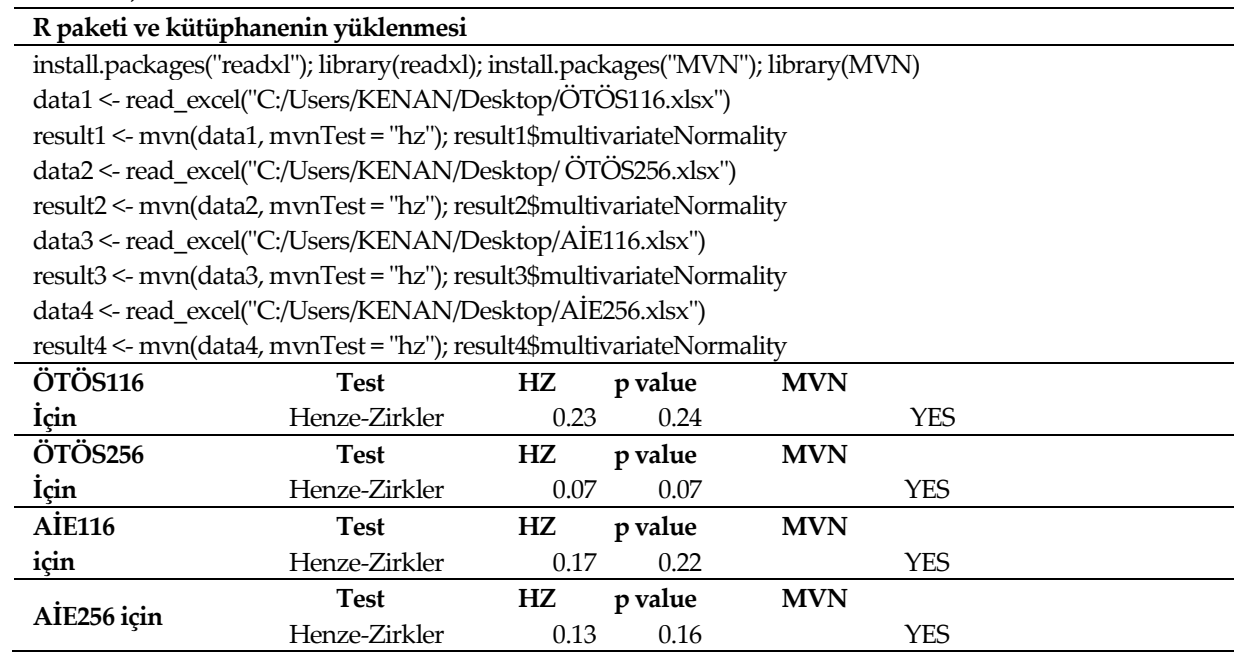


Tablo 3. Çalışmadaki İkinci Grup Verinin Değişkenlerin Ortalamasına Ait Normal Dağılımının Kontrolü ile İlgili Yapılan Testler (Python Programlama Dilinde)

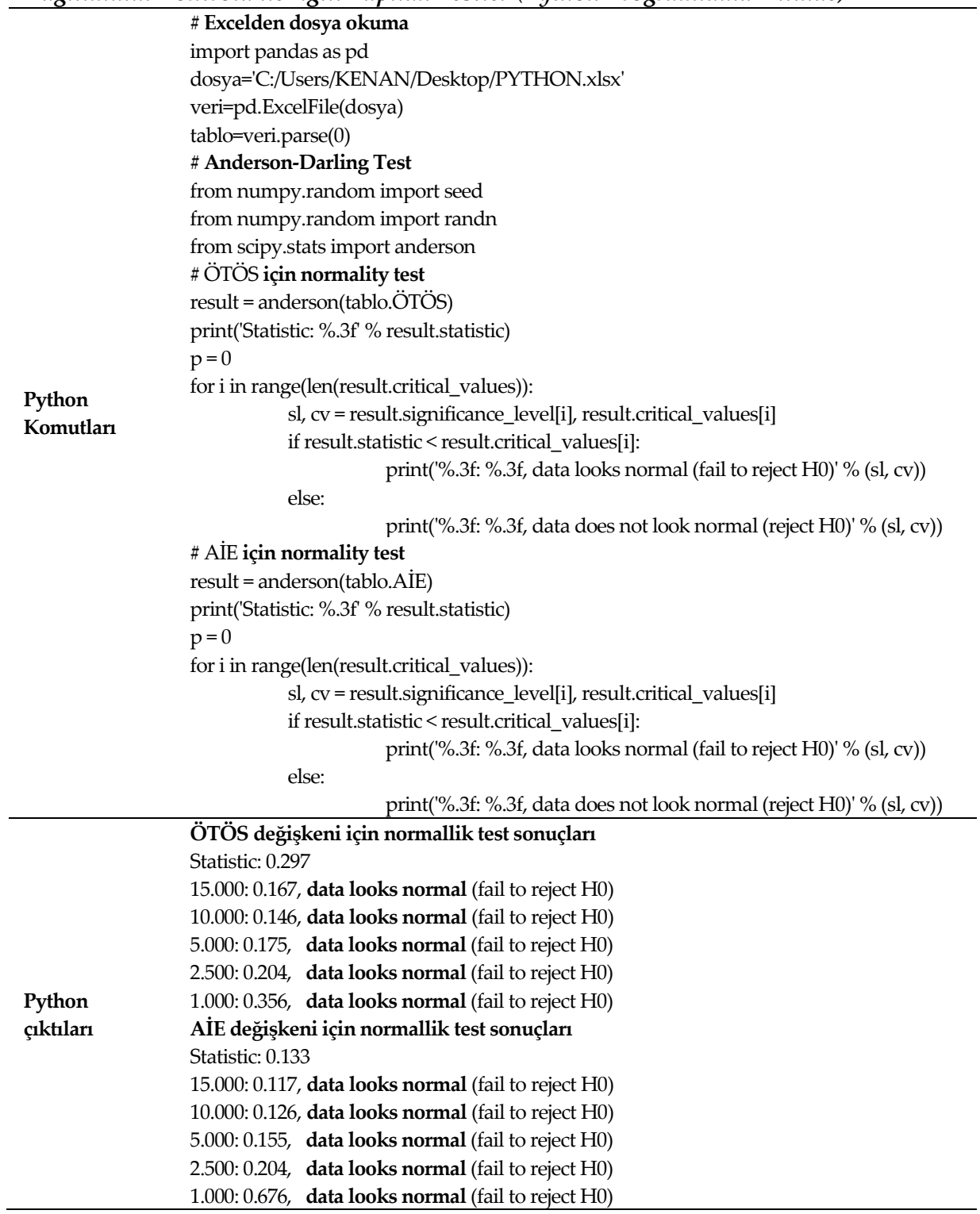

Tablo 2'de yer alan değerler incelendiğinde; her bir grubun anlamlılık değerinin $(p(0.07), p(0.016), p(0.22)$ ve $p(0.24)) 0.05$ anlamllık değerinin üze- 
rinde olduğundan ölçeklerin gözlem değerlerinin her iki grupta çok değişkenli normal ve Tablo 3'de yer alan değerler incelendiğinde; ölçeklerin ortalama değerlerinin her iki grupta normal dağıldığı tespit edilmiştir. Dolayısıyla çalışmadaki bütün verilerin yapılacak analizlerde güvenilir bir şekilde kullanılabileceği sonucuna ulaşılmıştır.

\section{Algılanan İstihdam Edilebilirlik Ölçeğinin Geçerlik ve Güvenirlik Çalışması}

Algılanan İstihdam Edilebilirlik Ölçeği ile ilgili olarak SPSS paket programında geçerlik ve güvenirlik çalışmaları ile ilgili yapılan analizlerin sonuçları Tablo 4, 5, 6, 7'de verilmiştir.

İlk olarak Algilanan İstihdam Edilebilirlik Ölçeği ile ilgili olarak verilerin faktörlenip faktörlenemeyeceğinin kontrolü için KMO değerleri hesaplanmiş ve Bartlett Küresellik Testi istatistikleri elde edilmiştir. Elde edilen analiz sonuçları Tablo 4'te yer almaktadır.

Tablo 4. KMO ve Bartlett Küresellik Testi

\begin{tabular}{lll}
\hline Kaiser-Meyer-Olkin (KMO) & & 0.816 \\
\hline \multirow{3}{*}{ Bartlett Küresellik Testi } & Ki-kare & 1278.423 \\
\cline { 2 - 3 } & Sd & 45 \\
\hline
\end{tabular}

Tablo 4'te yer alan analiz değerleri incelendiğinde; verilerin yapılması planlanan açılayıcı faktör analizi için uygun olduğuna karar verilmiştir (KMO>0.60 ve $p<0.01)$.

İkinci iş olarak açılayıc faktör analizinde Algılanan İstihdam Edilebilirlik Ölçeği verilerinin kaç faktör altında toplandığının ve her bir faktörün yüklerinin hesaplanması gerekmektedir. Bu kapsamda yapılan analiz neticesinde elde edilen sonuçlar Tablo 5 'te yer almaktadır. Analizde temel bileşenler yöntemi ve varimax döndürme yöntemi kullanılmıştır. 
Tablo 5. Döndürülmüş Faktör Yükleri

\begin{tabular}{|c|c|c|}
\hline & \multicolumn{2}{|c|}{ Faktörler } \\
\hline & 1 & 2 \\
\hline AiE7 & 0.877 & 0.197 \\
\hline AİE9 & 0.844 & 0.000 \\
\hline AIEE8 & 0.797 & 0.098 \\
\hline AİE6 & 0.744 & 0.108 \\
\hline AIE10 & 0.738 & 0.324 \\
\hline AiE5 & 0.612 & 0.253 \\
\hline AIIE3 & 0.093 & 0.773 \\
\hline AiE2 & 0.121 & 0.744 \\
\hline AIE4 & 0.324 & 0.717 \\
\hline AïE1 & -0.050 & 0.692 \\
\hline
\end{tabular}

Tablo 5'te yer alan değerler incelendiğinde; ölçek soru maddelerinin iki alt faktörde toplandığı ve faktör yüklerinin literatürde yer alan referans değerlerine uygun olduğuna (faktör yükleri>0.30) karar verilmiştir. Dolay1sıyla Gerçek ve Elmas Atay (2017) tarafından söz konusu ölçeğin Türkçe'ye uyarlanması esnasında elde edilen ölçeğin yapısıyla aynı sonuçlar elde edilmiştir.

Açıklayıcı faktör analizinde yapılması gereken üçüncü iş, belirlenen faktör sayısının toplam varyansı ne kadar açıkladığının kontrol edilmesidir. Bu kapsamda Algılanan İstihdam Edilebilirlik Ölçeği'nin iki alt boyutunun toplam varyansı ne kadar açıkladığı ile ilgili yapılan analiz sonucu Tablo $6^{\prime}$ da verilmiştir.

Tablo 6. Toplam Açıklanan Varyans

\begin{tabular}{|c|c|c|c|c|c|c|c|c|c|}
\hline \multirow{2}{*}{ Faktör } & \multicolumn{3}{|c|}{ İlk Özkökler } & \multicolumn{3}{|c|}{$\begin{array}{l}\text { Çıkartılmış Faktörlerin } \\
\text { Karelerinin Toplamı }\end{array}$} & \multicolumn{3}{|c|}{$\begin{array}{l}\text { Döndürülmüş Faktörlerin } \\
\text { Karelerinin Toplamı }\end{array}$} \\
\hline & Top. & $\begin{array}{l}\text { \% } \\
\text { Varyans }\end{array}$ & $\begin{array}{l}\% \\
\text { Kümülatif }\end{array}$ & Top. & $\begin{array}{l}\% \\
\text { Varyans }\end{array}$ & $\begin{array}{l}\% \\
\text { Kümülatif }\end{array}$ & Top. & $\begin{array}{l}\% \\
\text { Varyans }\end{array}$ & $\begin{array}{l}\text { \% } \\
\text { Kümülatif }\end{array}$ \\
\hline 1 & 4.347 & 43.46 & 43.465 & 4.347 & 43.465 & 43.465 & 3.40 & 34.08 & 34.08 \\
\hline 2 & 2.032 & 20.32 & 63.787 & 2.032 & 20.322 & 63.787 & 2.97 & 29.70 & 63.78 \\
\hline$\underline{3}$ & 0.770 & 7.702 & 71.489 & & & & & & \\
\hline$\underline{4}$ & 0.693 & 6.928 & 78.417 & & & & & & \\
\hline$\underline{5}$ & 0.573 & 5.728 & 84.145 & & & & & & \\
\hline 6 & 0.501 & 5.014 & 89.159 & & & & & & \\
\hline 7 & 0.366 & 3.659 & 92.818 & & & & & & \\
\hline$\underline{8}$ & 0.322 & 3.218 & 96.036 & & & & & & \\
\hline 9 & 0.228 & 2.283 & 98.319 & & & & & & \\
\hline 10 & 0.168 & 1.681 & 100.000 & & & & & & \\
\hline
\end{tabular}


Tablo 6'da yer alan değeler incelendiğinde; Algılanan İstihdam Edilebilirlik Ölçeği'nin iki alt boyutunun toplam varyansın \%63.78'ini açıkladığ görülmektedir. Literatürde konu ile ilgili benzer çalışmalar incelendiğinde söz konusu değerin yeterli olduğu tespit edilmiştir.

Algılanan İstihdam Edilebilirlik Ölçeği'nin geçerlik analizlerinin yapılmasından sonra yapılması gereken son iş ise güvenirliğinin kontrol edilmesi ile ilgili olarak Cronbach Alpha katsayısınin hesap edilmesidir. SPSS paket programında yapılan analiz sonucu Tablo $7^{\prime}$ de verilmiştir.

Tablo 7. Cronbach Alpha Katsayısı İstatistikleri

\begin{tabular}{llr}
\hline Cronbach Alpha & \multicolumn{1}{c}{ Standardize Edilmiş Cronbach Alpha N } \\
\hline 0.850 & 0.861 & 10 \\
\hline
\end{tabular}

Tablo 7'de yer alan Cronbach Alpha katsayısının değeri incelendiğinde; söz konusu katsayısı değerinin literatürde yer alan benzer çalışmalar ile uyumlu olduğu ve Alpar (2012) tarafından hazırlanmış yayında yer alan çizelgeye göre ise ölçeğin "oldukça güvenilir bir ölçek" olduğu sonucuna ulaşılmıştır.

\section{Algılanan İstihdam Edilebilirlik ve Örgüt Temelli Özsaygı Ölçeklerinin Doğrulayıcı Faktör Analizi}

Çalışmada kullanılan ölçeklerin yapıları ortaya konduktan sonra analizlerde kullanılan verilerin ölçeklere uygun olup olmadığının kontrolü doğrulayıcı faktör analizi ile kontrol edilmiştir. Doğrulayıcı faktör analizinde ikinci grup örneklem $(n=256)$ kullanılmış ve analizler AMOS paket programında yapılmıştır. AMOS paket programında yapılan ölçeklere ait doğrulayıcı faktör analizinin şekilsel gösterimi Şekil 2'de ve Şekil 3'te yer almaktadır. Ayrıca yapılan doğrulayıcı faktör analizleri neticesinde ölçeklere ait uyum iyiliği değerleri ise Tablo $8^{\prime}$ de gösterilmiştir. 

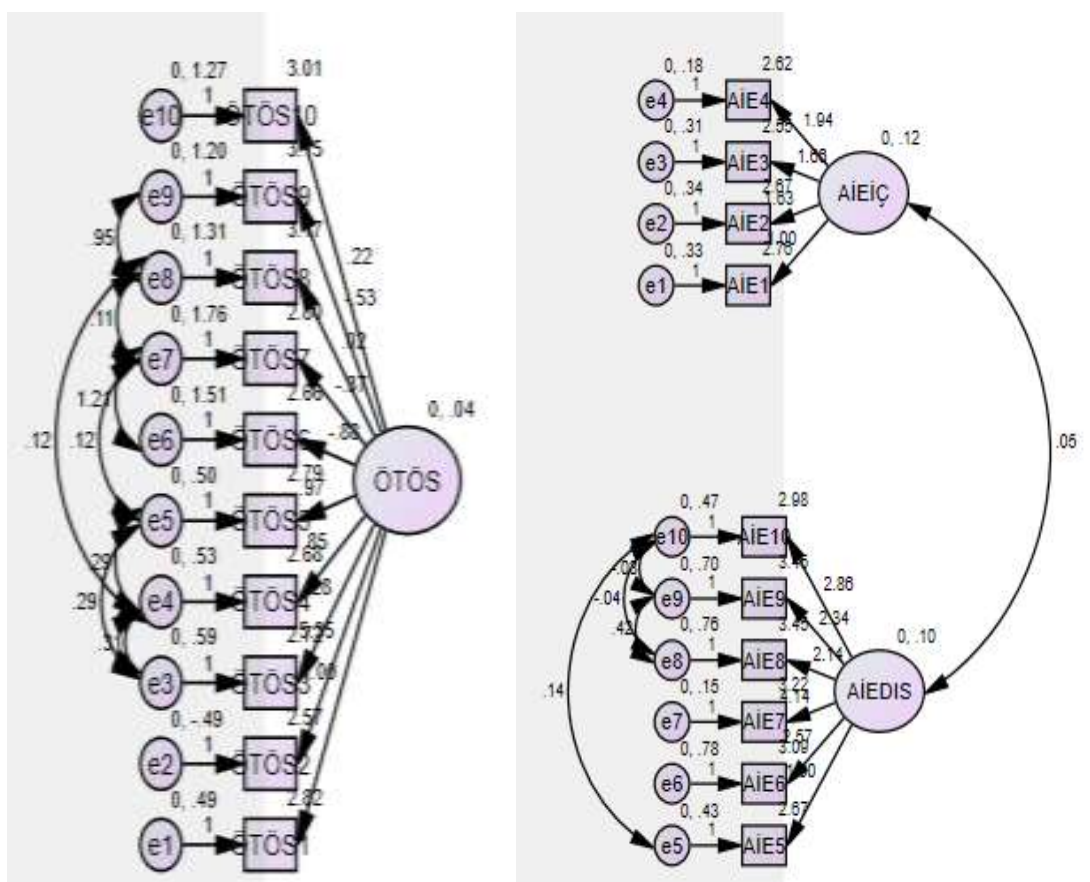

Şekil 2. Örgüt Temelli Özsaygı Şekil 3. Algılanan İstihdam Edilebilirlik

Tablo 8. Ölçeklerin Uyum İyilik Değerleri

\begin{tabular}{llllllll}
\hline Ölçekler & $\chi^{2}$ & sd & $\chi^{2} /$ sd & CFI & RMSEA & TLI & NFI \\
\hline Örgüt Temelli Özsaygi Ölçeği & 174.919 & 27 & 6.47 & 0.953 & 0.047 & 0.938 & 0.923 \\
\hline $\begin{array}{l}\text { Algilanan İstihdam } \\
\text { Edilebilirlik Ölçeği }\end{array}$ & 167.535 & \multirow{2}{*}{30} & 5.58 & 0.96 & 0.094 & 0.936 & 0.901
\end{tabular}

p>0,05; CFI $>0.95$ :Comparative Fit Index (Karşılaştırmal Uyum Indeksi); RMSEA<0.08:Root Mean Square Error of Approximation (Yaklaşık Hatalarm Ortalama Karekökü); TLI $>0.90$ : TuckerLewis Indeksi (Tucker-Lewis Index); NFI>0.90: Normed Fit Index (Normlaştırılmış Uyum Indeksi)

Meydan, C.H. ve Şeşen, H. (2015). Yapısal Eşitlik Modellemesi: AMOS Uygulamaları, Detay Yaymları, Ankara.

Tablo 8'de yer alan uyum iyiliği değerleri incelendiğinde; bütün uyum iyilik değerlerinin literatürdeki referans değerleri ile uyum içinde ve kabul edilebilir olduğu, ancak $\chi^{2} / \mathrm{sd}$ değerinin ise referans değerlerini biraz aştı̆̆ 1 (kabul edilebilir uyum:3 > $\chi^{2} / \mathrm{sd}>5$ ) ancak çeşitli çalışmalar incelendiğinde 
yapılacak analizlerde sorun olmayacağı değerlendirilmiştir. Referans değerleri ile ilgili detaylı bilgilere Tablo 8'in altında da açıklandığı üzere Meydan ve Şeşen (2015) tarafından hazırlanmış yayına bakılabilir.

\section{Bulgular}

Çalışmanın bu bölümünde değişkenler arasındaki ilişki ile bu ilişkide cinsiyet değişkeninin düzenleyicilik etkisi olup olmadığı korelasyon ve regresyon analizleri ile araştırılmış ve elde edilen bulgular yorumlanmıştır.

\section{Algılanan İstihdam Edilebilirlik ve Örgüt Temelli Özsaygı Değişkenleri Arasındaki İlişkinin İncelenmesi}

Algilanan istihdam edilebilirlik ve örgüt temelli özsaygı değişkenleri arasındaki nedensellik ilişkisi ve cinsiyetin düzenleyici etkisi incelemeden önce söz konusu değişkenler arasında ilişkinin durumunun irdelenmesi gerekmektedir. Bu amacı gerçekleştirmek maksadıyla değişkenlerin ortalama ve standart sapma değerleri ile korelasyon katsayısı değerlerine bakmak gerekir. Bu kapsamda Python programlama dilinde yazılan kodlar kapsamında değişkenler ile ilgili elde edilen analiz sonuçları Tablo 9'da yer almaktadır.

Tablo 9. Değişkelere Ait Ortalama, Standart Sapma ve Korelasyon Katsayısı Değerleri

\begin{tabular}{lllll}
\hline \multicolumn{5}{l}{ Değişkenler Arasındaki İlişki Katsayısının Hesaplanmasında Kullanılan Python Kodları } \\
\hline Değişkenler & Ortalama & Standart Sapma & ÖTÖS & AİE \\
\hline Örgüt Temelli Özsaygı (ÖTÖS) & 2.830 & 0.51 & 1 & \\
\hline Algılanan İstihdam Edilebilirlik (AİE) & 3.007 & 0.68 & $0.678^{*}$ & 1 \\
\hline${ }^{*} \mathrm{p}<0.01$ & & & &
\end{tabular}

Tablo 9'da yer alan değerler incelendiğinde; değişkenlerin ortalama değerlerinin birbirine yakın ve standart sapma değerlerinin ise oldukça güvenilir sonuçlar verdiği tespit edilmiştir. Değişkenler arasındaki ilişki katsay1ları ise anlamlı olduğu ve aradaki ilişkinin aynı yönlü ve kuvvetli bir ilişkinin olduğu sonucuna ulaşılmıştır. Bu sonuçlara bağlı olarak kurulan bir nolu hipotezin kabul edildiği anlamına gelmektedir.

Korelasyon katsayılarının yorumlanmasında Alpar (2012) tarafindan hazırlanmış yayının 338. sayfasındaki "Pearson $\mathrm{r}$ için Nitelendirme Tablo- 
su"dan yararlanılmış olup detaylı bilgilere söz konusu yayına bakılarak ulaşılabilir.

\section{Algılanan İstihdam Edilebilirlik ve Örgüt Temelli Özsaygı Değisşkenleri Arasındaki İlişki ile Cinsiyetin Düzenleyici Etkisinin İncelenmesi}

Çalışmada kullanılan iki değişken olan algılanan istihdam edilebilirlik ve örgüt temelli özsaygı değişkenlerinin arasındaki nedensellik ilişkisi ile cinsiyetin düzenleyici etkisinin ortaya konması amacıyla Baron ve Kenny'nin düzenleyici etkiyi tespit etmekte kullandığı analiz yöntemi olan hiyerarşik regresyon analizi kullanılmış (çalışmada hiyerarşik regresyon analizinin iki değişken arasındaki basit regresyon analiz sonuçları anlamlı bulunmuş ve bu çalışmada gösterilmemiştir.) ve söz konusu analiz ve SSPS paket programın PROCESS modülünde yapılmıştır. Çalışmada bağımlı değişken $(Y)$ olarak AİE, bağımsız değişken olarak ÖTÖS $(X)$ ve cinsiyet (düzenleyici değişken, W) değişkenleri ve bağımsız değişken ve aynı zamanda etkileşim terimi olarak ÖTÖS ve cinsiyet değişkeninin çarpımı $\left(X{ }^{*} W\right)$ sonucunda elde edilen gözlem değerleri alınmıştır. Çalışmada kullanılan tüm değişkenlerin ortalaması merkezileștirilerek analize dâhil edilmiştir. Analizde, bağımsız değişken ile düzenleyici değişkenin birbiriyle çarpılması sonucunda ortaya çıan etkileşim değişkeninin anlamlı olması durumunda, düzenleyici etkinin varlığı kabul edilmektedir (Baron ve Kenny, 1986).

Değişkenler ile kurulan modelin analizi yapılmadan önce mutlaka regresyon modeli ile ilgili olarak uygulanması gereken varsayımların kontrol edilmesi gerekmektedir. Bu kapsamda regresyon modeli ile ilgili olarak bütün sağlanması gereken varsayımların hepsinin sağlandığı görülmüştür. Varsayımlar kapsamında değişkenlerin çok değişkenli normal dağılması ile ilgili olarak önceki bölümlerde gerekli olan test yapılmıştır. Ayrıca önemli olan diğer bir test ise modelde çoklu doğrusal bağlantı problemi de incelenmiştir. Yapılan analiz sonucunda VIF değerlerinin (ÖTÖS:3.16, CINSIY:4.54, ÖTÖSxCINSIYY:4.18) hepsinin literatürde genel kabul görmüş olan 5 referans değerinin altında olduğu tespit edilmiştir. Bu kapsamda varsayımların kontrol edilmesinden sonra kurulan regresyon modeli ile ilgili elde edilen sonuçlar çizelge halinde Tablo 10 'da verilmiştir. 
Tablo 10. Düzenleyici Etkinin İncelendiği Hayes-1 Modelinin Analiz Sonuçlar

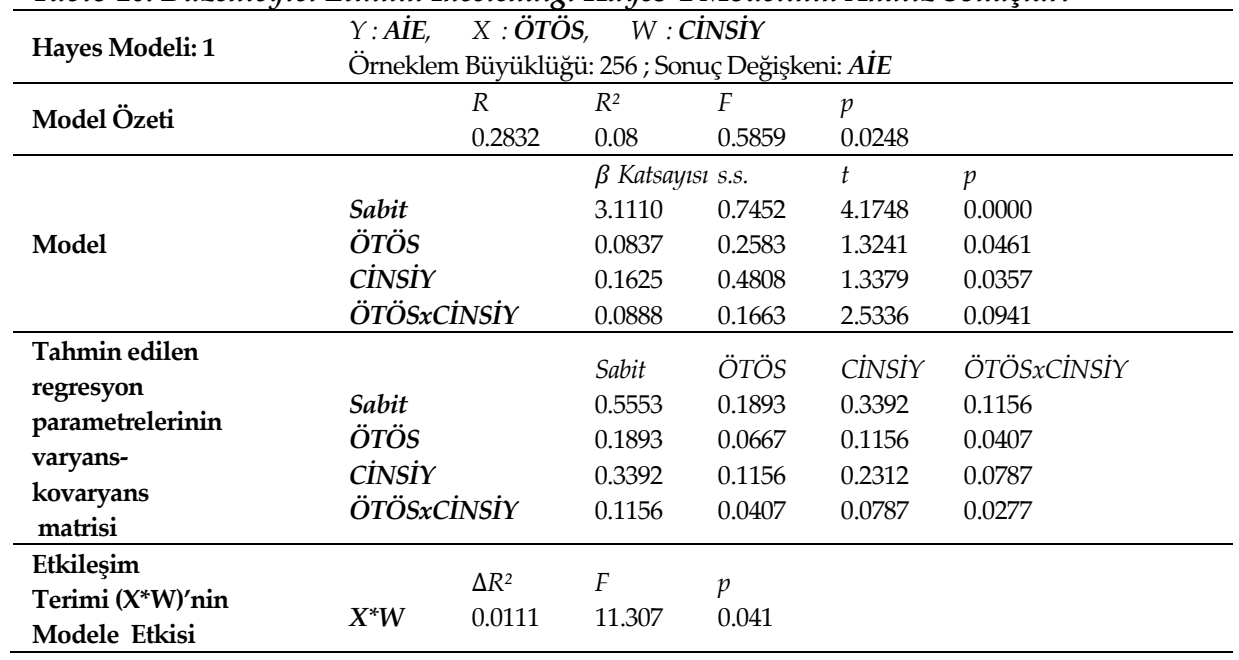

Tablo 10'da yer alan sonuçlar incelendiğinde; kurulan modeli bir bütün olarak anlamlılığını sinayan $\mathrm{F}$ testine göre modelin anlamlı $(F=0.5859$, $p(0.0248)<0.05)$, kurulan modeldeki sabit ve regresyon katsayıların sınayan $\mathrm{t}$ testine göre katsayıların anlamlı (sabit: $p(0.000)<0.1$ ÖTÖS: $p(0.0461)<0.1$, CINSIYY: $p(0.0357)<0.1$, ÖTÖSxCINSIYY: $p(0.0941)<0.1)$ ve etkileşim teriminin $\left(X^{*} \mathrm{~W}\right)$ modele dahil edildiğinde modelin bir bütün olarak yine anlamlı ve belirlilik katsayısında artış olduğu ve dolayısıyla sonuç olarak etkileşim terimini modele pozitif yönde bir artış kattığı sonucuna ulaşılmıştır. Bu durumda cinsiyetin örgüt temelli özsaygı değişkeni ile algılanan istihdam edilebilirlik değişkeni arasında düzenleyici bir rol oynadığı ve bu sonuca göre iki numaralı hipotezin kabul edildiği sonucuna ulaşılmıştır.

Cinsiyetin örgüt temelli özsaygı değişkeni ile algılanan istihdam edilebilirlik değişkeni arasında düzenleyici bir rol oynadığı ortaya konulduktan sonra yapılması gereken işlem ise cinsiyetin kategorilerine göre (yapılan çalışmada cinsiyet değişkeni 1:kadın ve 2:erkek kategorileri) regresyon doğrusunu çizerek cinsiyetin iki değişken arasında nasıl rol oynadığını ortaya koymaktır. Çizilen regresyon eğrisiyle, cinsiyet düzenleyici değişkeninin kadın ve erkek olduğu durumlarda algılanan istihdam edilebilirlik ile örgüt temelli özsaygı arasındaki ilişkilerin anlamlılığı test edilmiştir (Aiken ve West, 1991; Cohen, Cohen, West ve Aiken, 2003). Bu kapsamda cinsiyet değişkeninin kadın ya da erkek durumlarında algılanan istihdam edilebilirlik ile örgüt 
temelli özsaygı arasındaki ilişkinin nasıl bir değişim gösterdiğinin tespit edilmesinde Aiken ve West (1991)'in basit eğim testi kullanılmıştır. Böylece, cinsiyetin erkek ve kadın seviyelerinin algılanan istihdam edilebilirlik ile örgüt temelli özsaygı arasındaki ilişkide nasıl bir performans gösterdiği ile ilgili oluşturulan grafik Şekil 4'te verilmiştir.

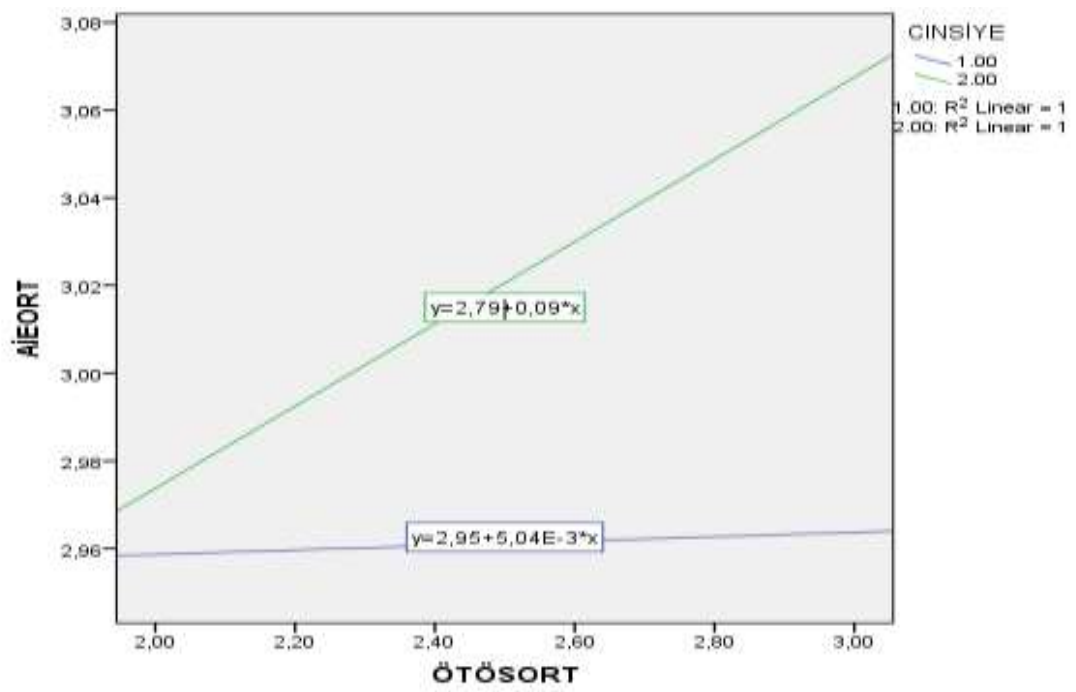

Şekil 4. AİE ve ÖTÖS Değişkenleri Arasındaki İlişkide Cinsiyetin (1:Kadın, 2:Erkek) Etkisi

Şekil 4'te yer alan grafik incelendiğinde; yeşil doğru cinsiyet değişkeninin kadın ( $W=1)$ olduğunda çizilen regresyon doğrusu ve mavi doğru ise cinsiyet değişkeninin erkek ( $W=2)$ olduğunda çizilen regresyon doğrusudur. Grafikte $W$ değişkeni (cinsiyet) 1 değerini (kadin) aldığında regresyon doğrusu $y=2.79+0.09 x$ ve $W$ değişkeni (cinsiyet) 2 değerini (erkek) aldığında ise regresyon doğrusu $y=2.95+5.04 e-3 x$ olmaktadır. Her iki regresyon doğrusunda da kadın ve erkeklerde örgüt temelli özsaygının düşük olduğunda algılanan istihdam edilebilirlik seviyesinin düşük ve birbirine yakın değerler aldığı, örgüt temelli özsaygının değerinin arttığı durumlarda kadınlarda algılanan istihdam edilebilirlik seviyesinin hemen hemen aynı kaldığı ancak erkeklerde algılanan istihdam edilebilirlik seviyesinin oldukça arttığı ve her iki cins arasında da farklılığın oluştuğu görülmektedir. 


\section{Sonuç ve Değerlendirme}

Yapılan çalışmada örgüt temelli özsaygı ile algılanan istihdam edilebilirlik kavramları arasındaki ilişki ve söz konusu ilişkide cinsiyetin düzenleyici etkisinin olup olmadığı araştırılmıştır. Bu kapsamda çalışmada kullanılan veriler iki adet ölçeğin 5 devlet üniversitesinde görevli 372 akademisyene uygulanarak toplanmıştır. Verilerin analizi için, SPSS paket programı PROCESS modülü, AMOS paket program, Python programlama dili ve R programlama dili kullanılmıştır.

Çalışmanın sonunda örgüt temelli özsaygının algılanan istihdam edilebilirliği pozitif yönde güçlü olarak etkilediği, aralarında nedensellik ilişkisinin olduğu ve cinsiyetin düzenleyici bir rol oynadığı tespit edilmiştir. Kadın ve erkeklerde örgüt temelli özsayginın düşük olduğunda algılanan istihdam edilebilirlik seviyesinin düşük ve birbirine yakın değerler aldığı, örgüt temelli özsaygının değerinin arttı̆ı durumlarda kadınlarda algılanan istihdam edilebilirlik seviyesinin hemen hemen aynı kaldığı ancak erkeklerde algilanan istihdam edilebilirlik seviyesinin oldukça arttığı ve her iki cins arasında da oldukça büyük bir farklılığın oluştuğu tespit edilmiştir. Dolay1sıyla, örgüt temelli özsaygı ile algılanan istihdam edilebilirlik arasında anlamlı ve aynı yönlü bir ilişki bulunduğu ve örgüt temelli özsaygı ile algılanan istihdam edilebilirlik arasındaki ilişkide cinsiyetin düzenleyici bir etkisinin bulunduğu tespit edilmiştir.

Bu kapsamda insanlara çalıştığı örgütten ve örgütteki rolünden dolayı değer verilmesi durumunda, insanlar örgütün bir parçası olma konusunda daha fazla gayret gösterebilir. Bu durum, örgütün insanlarda oluşturduğu algının, toplumda oluşturduğu imajın çok önemli olduğunu gösterir. Bunun için insanların iş sahibi olmaktan öte üyesi olmaktan gurur duyacağı, örgütün vizyonu, misyonu ve değerleri ile ayn zamanda üyelerinin de amaç ve hedeflerini karşılayacağı bir düşünceyle hareket etmesi gerekir. Böyle bir yaklaşım, nitelikli insanları örgüte çekecek, insanların örgütsel vatandaşlık davranışı sergilemesini sağlayacak, örgüte bağlılıklarını artıracak, üretkenlik dışı davranışlaır ise ortadan kaldıracaktır. Örgüte katılan kişiler nitelikli kişilerdir. Böyle bir ortam yaratıldığı takdirde, tatmin edildikçe daha çok motivasyon sağlayan kendini gerçekleştirme davranışı bu kişilerin mevcut niteliklerini de artıracaktır. 
Erkeklerde örgüt temelli özsaygının arttıkça algılanan istihdam edilebilirlik seviyesinin artması, kadınlarda ise bir değişiklik olmaması, toplumda kadın ve erkeğe yüklenen rollerden kaynaklanabilir. Statü ve ücret gibi hususlar genellikle erkeklere atfedilen mücadele ve hurs gibi kavramlarla yakından ilgilidir. Dolayısıyla erkekler istihdam edilebilirlik durumunu artırma konusunda bir gayret gösterecektir. Her ne kadar bu durum bir rekabet ortamı yaratacak olsa da bu, örgütün ve çalışanların lehine bir durum olacaktır. Kadınların algılanan istihdam edilebilirlik konusunda yaklaşımlarının değişmemesi ise kadının hırslı olmamak, öne çıkmamak, erkeği desteklemek gibi toplumsal öğretilerden kaynaklanabilir. Bu durum, kadınlar için örgüt temelli özsaygıdan ziyade kadınların kendilerine olan saygının daha önemli olmasından ve bu saygı için herhangi bir elemana ihtiyaç duymamasından da kaynaklanabilir. Bunun nedeni de araştırma örnekleminin akademisyenlerden seçilmesi olabilir.

Bu araştırmanın bazı kısıtları da bulunmaktadır. Araştırmanın boylamsal olmaması bu araştırmanın en önemli kısıtıdır. Diğer bir kısıt ise araştırmanın akademisyenler üzerinde yapılmasıdır. Bu araştırmanın farklı sektörlerde yapılması farklı sonuçları ortaya çıkarabilir. Ayrıca örgüt kültürü, örgüt iklimi, liderlik yaklaşımları, başarı ihtiyacı gibi değişkenler de sonuçları etkileyebilir. Dolayısıyla araştırmada ele alınan değişkenlerin öncüllerinin ve ardıllarının da dikkate alındığı çalışmalara ihtiyaç duyulduğu söylenebilir. 


\title{
EXTENDED ABSTRACT
}

\section{The Moderating Effect of Gender in Relationship between Organization-Based Self-Esteem and Self-Perceived Employment, and an Application}

\author{
Kenan Orçanl1 \\ Toros University
}

The aim of the present study is to examine the effect of the gender factor, which is considered to have a moderator role in the relationship between organization-based self-esteem and self-perceived employment, which are two important concepts in the organizational behavior literature today. The hypotheses established in this context are as follows.

- Hypothesis 1: There is a significant and same-way relationship between organization-based self-esteem and self-perceived employment.

- Hypothesis 2: Gender has a moderator effect in the relationship between organization-based self-esteem and self-perceived employment.

The data used in the study was gathered with two scales applied to 256 academics working in 5 universities located in Ankara and Mersin provinces and the model established in which the gender factor has a regulatory effect in the relationship between variables, was tested in the SPSS package program PROCESS module, in the AMOS package program and in Python programming language (confirmatory factor analysis, correlation analysis and regression analysis). Validity and reliability analysis results of the scales used in the study are below.

\begin{tabular}{|c|c|c|c|c|c|c|c|c|}
\hline \multicolumn{2}{|c|}{ Scale } & $\chi^{2}$ & s.d. & $\chi^{2 / s d}$ & CFI & RMSEA & TLI & NFI \\
\hline 1 & $\begin{array}{c}\text { Organization-based } \\
\text { self-esteem scale }\end{array}$ & 174.919 & 27 & 6.47 & 0.953 & 0.047 & 0.938 & 0.923 \\
\hline 2 & $\begin{array}{c}\text { Self-perceived } \\
\text { employment scale }\end{array}$ & 167.535 & 30 & 5.58 & 0.96 & 0.094 & 0.936 & 0.901 \\
\hline
\end{tabular}


When the goodness of fit values of the scales in the table are examined, it can be said that the goodness of fit values of all three scales are compatible with the reference values in the literature.

The results obtained regarding the relationship between the variables are below.

\begin{tabular}{|c|c|c|c|c|c|}
\hline Variables & Mean & s.s. & & $\begin{array}{c}\text { Organization-based } \\
\text { self-esteem }\end{array}$ & $\begin{array}{c}\text { Self-perceived } \\
\text { employment }\end{array}$ \\
\hline \multirow{2}{*}{$\begin{array}{c}\text { Organization-based } \\
\text { self-esteem }\end{array}$} & \multirow{2}{*}{2.830} & \multirow{2}{*}{0.51} & $\mathrm{r}$ & 1 & 0.658 \\
\hline & & & $p$ & & $p<0.01$ \\
\hline \multirow{2}{*}{$\begin{array}{c}\text { Self-perceived } \\
\text { employment }\end{array}$} & \multirow{2}{*}{3.007} & \multirow{2}{*}{0.68} & $\mathrm{r}$ & 0.658 & 1 \\
\hline & & & $p$ & $\mathrm{p}<0.01$ & \\
\hline
\end{tabular}

- There is a significant and moderate relationship between organizationbased self-esteem and self-perceived employment $(r=0.658$, $p(0.000)<0.01)$,

The results of the regression analysis applied to investigate causality relationships between variables in the study are below.

\begin{tabular}{|c|c|c|}
\hline $\begin{array}{c}\text { Independent } \\
\text { Variable/Variables }\end{array}$ & Dependent Variable & $\begin{array}{c}\text { Relationship } \\
\text { Status }\end{array}$ \\
\hline $\begin{array}{c}\text { Organization-based } \\
\text { self-esteem }\end{array}$ & Self-perceived employment & Significant \\
\hline
\end{tabular}

At the end of the study, it was confirmed that there was a positive and same-way relationship between organization-based self-esteem and selfperceived employment, and it was found that the gender of the employees played a moderator role in the relationship between organization-based self-esteem and self-perceived employment.

The results obtained regarding the hypotheses established in this context are shown in the table below.

\begin{tabular}{|l|l|l|}
\hline$H_{1}$ & $\begin{array}{l}\text { There is a significant and same-way relationship } \\
\text { between organization-based self-esteem and } \\
\text { self-perceived employment. }\end{array}$ & Accepted \\
\hline$H_{2}$ & $\begin{array}{l}\text { Gender has a moderator effect in the relations- } \\
\text { hip between organization-based self-esteem and } \\
\text { self-perceived employment. }\end{array}$ & Accepted \\
\hline
\end{tabular}


It is evaluated that the result presented in this way both will contribute to the organizational behavior literature and will be beneficial for people who are in managerial positions in businesses and those who work in a workplace for a fee.

This research also has some limitations. The fact that the research is not longitudinal is the most important limitation of this research. Another limitation is that the research is carried out on academics. Conducting this research in different sectors may reveal different results. In addition, variables such as organizational culture, organizational climate, leadership approaches, and the need for success can also affect the results. Therefore, it can be said that studies that take into account the premises and successors of the variables discussed in the research are needed.

\section{Kaynakça / References}

Aiken, L. S. ve West, S. G. (1991). Multiple regression: Testing and interpreting interactions. Newbury Park, CA: Sage Publications.

Akalın, Ç. (2006). Duygusal örgütsel bağhllık gelişiminde çalışanların algıladığı örgütsel destek ve ara bir değiş̧ken olarak örgüt temelli öz-saygı. Yayımlanmamış Yüksek Lisans Tezi. Hacettepe Üniversitesi, Sosyal Bilimler Enstitüsü, Ankara.

Alpar, R. (2012). Çok Değişkenli İstatistiksel Yöntemler. Detay Yayıncılık, Ankara.

Aybas, M. ve Kırbaşlar M. (2014). Hırs, iç kontrol odaklılık ve yenilikçiliğin iş gücü piyasası adaylarının istihdam edilebilirlik algıları üzerindeki etkisi. Research Journal of Business and Management 1(4), 353-364.

Baron, R.M. ve Kenny, D.A. (1986). The moderator mediator variable distinction in social psychological research: Conceptual, Strategic, and statistical considerations. Journal of Personality and Social Psychology, 51, 1173-1182.

Başgüt, S. (2019). Algilanan örgütsel destek ve psikolojik sahiplenme ilişkisinde örgüt temelli özsaygının rolü. Yayımlanmamış Yüksek Lisans Tezi. İnönü Üniversitesi, Sosyal Bilimleri Enstitüsü, Malatya.

Bekmezci, M,. Orçanl, K. ve Görmen, M. (2020), Yetkinlik geliştirmenin kariyer tatmini ve 1ş performansina etkisi: Algilanan stihdam edilebilirliğin aracilik rolü. Erciyes Üniversitesi İ̈BF Dergisi,

Berntson, E., Sverke, M. ve Marklund, S. (2006). Predicting perceived employability: Human capital or labour market opportunities? Economic and Industrial Democracy 27(2), 223-244. 
Berntson, E. ve Marklund, S. (2007). The relationship between perceived employability and subsequent health. Work \& Stress, 21(3), 279-292.

Bowling, N. A., Eschleman, K. J., Wang, Q., Kirkendall, C. ve Alarcon, G. (2010). A meta-analysis of the predictors and consequences of organization-based self-esteem. Journal of Occupational and Organizational Psychology, 83(3), 601-626.

Cohen, J., Cohen, P., West, S.G. ve Aiken, L.S. (2003). Applied multiple regression/correlation analysis for the behavioral sciences. Inc: Mahwah, New Jersey: Lawrence Erlbaum Associates

De Cuyper, N., Van der Heijden, B. I., ve De Witte, H. (2011). Associations between perceived employability, employee well-being, and its contribution to organizational success: A matter of psychological contracts?. The International Journal of Human Resource Management, 22(7), 1486-1503.

Eygü, H. ve Güllüce, A.Ç. (2017). Determination of customer satisfaction in conservative concept hotels by ordinal logistic regression analysis. Journal of Financial Risk Management, 6, 269-284.

Erdem, H., Kılınç, E. ve Demirci, D. (2016). Çalışanlarda iş yükü fazlalığın algılanan istihdam edilebilirlik üzerine etkisi. Elektronik Sosyal Bilimler Dergisi, 15(58), 772-784.

Erden, N.S. (2011). Örgüte bağlllk ile örgütsel adalet arasindaki ilişkide örgüt temelli özsaygının rolü. Yayımlanmamış Yüksek Lisans Tezi. Marmara Üniversitesi Sosyal Bilimler Enstitüsü, İstanbul.

Ergeneli, A. (2017). Örgütsel Davranı̧̧. Nobel, Ankara.

Forrier, A. ve Sels, L. (2003). The concept employability: A complex mosaic. International Journal of Human Resources Development and Management, 3, 102124.

Forrier, A., Verbruggen, M. ve De Cuyper, N. (2015). Integrating different notions of employability in a dynamic chain: The relationship between job transitions, movement capital and perceived employability. Journal of Vocational Behavior, 89, 56-64.

Fugate M., Kinicki, A.J. ve Ashforth B.E. (2004). Employability: A psycho-social construct, its dimensions, and applications. Journal of Vocational Behavior, $65,14-38$.

Gardner, D.G., Wickramasinghe, V. ve Pierce, J.L. (2018). Values congruence, organization-based self-esteem, and employee responses: Evidence from Sri Lanka. International Journal of Cross Cultural Management, 18 (3), 349-372. 
Gerçek, M. ve Atay, Elmas, S. (2017). Rothwell ve Arnold'ın algılanan istihdam edilebilirlik ölçeği'nin Türkçe'ye uyarlama, geçerlilik ve güvenirlik çalışması. Dumlupınar Üniversitesi Sosyal Bilimler Dergisi, 54, 91-103.

Heijde, C.M.V. ve Heijden, B. (2005). The development and psychometric valuation of a multi-dimensional measurement insturement of employability and the impact of aging. International Congress Series, 1280, 143.

Keleş, E. (2015). Yaşam doyumunu yordayan örgütsel değgişkenler: Örgüt temelli özsaygının düzenleyici rolü. Yayımlanmamış Yüksek Lisans Tezi. Mersin Üniversitesi, Mersin.

Korman, A.K. (1976). Hypothesis of work behavior revisited and an extension. Academy of Management Review,1(1), 50-63.

Maslow, A.H. (1943). A theory of human motivation. Psychological Review, 50(4), 370-396.

McColl-Kennedy, J.R., ve Anderson, R.D. (2005). Subordinate-manager gender combination and perceived leadership style influence on emotions, selfesteem and organizational commitment. Journal of Business Research, 58(2), 115-125.

McQuaid, R.W. ve Lindsay, C. (2005). The concept of employability. Urban studies, 42(2), 197-219.

Meydan, C.H. ve Şeşen, H. (2011). Yapısal Eşitlik Modellemesi AMOS Uygulamaları. Detay Yayımcilık, Ankara.

Mruk, C.J. (2006). Self-Esteem research, theory, and practice: Toward a positive psychology of self-esteem, Springer Publishing Company, Third Edition, New York.

Fırat, M.Z., Orçanlı, K. ve Bekmezci, M. (2019). Kendi kendini istihdam etme ölçeğinin geçerlik ve güvenirlik çalışması ve örgüt temelli özsaygının kendi kendini istihdam etmeye etkisi. Mersin Üniversitesi Sosyal Bilimler Dergisi, 3(1), 6-24.

Özçelik Bozkurt, H. ve Özkoç, A.G. (2019). Çalışanlarda öznel iyi olma halinin algılanan istihdam edilebilirlik ve işten ayrılma niyeti ile ilişkisi: Konaklama işletmelerinde bir uygulama. Journal of Tourismand Gastronomy Studies, 7(1), 265-285.

Pierce, J.L., Gardner, D.G., Cummings, L.L. ve Dunham, R.B. (1989). Organizationbased self-esteem: Construct definition, measurement, and validation. Academy of Management journal, 32(3), 622-648. 
Pierce, J. ve Gardner, D. (2004). Self esteem within the work and organizational context: A review of organization-based self esteem literature. Journal of Management, 30(5), 591-622.

Rothwell, A. ve Arnold, J. (2007). Self-perceived employability: Development and validation of a scale. Personnel Review, 36(1), 23-41.

Rothwell, A., Herbert, I. ve Rothwell, F. (2008). Self-perceived employability: Construction and initial validation of a scale for university students. Journal of vocational behavior, 73(1), 1-12.

Sui, Y. ve Wang, H. (2014). Relational evaluation, organization- based self-esteem, and performance: The moderating role of allocentrism. Journal of Leadership and Organizational Studies, 21(1), 17-28.

Sumanasiri, E.G.T., Ab Yajid, M.S. ve Khatibi, A. (2016). Organization-based selfesteem (OBSE) and its influence on self-perceived employability (SPE) of IT export sector employees in Sri Lanka. European Scientific Journal, 12(14), 124-133.

TDK. (t.y). 24.10 .2019 tarihinde https://sozluk.gov.tr/ adresinden erişilmiştir.

Uçar, D. (2009). Algılanan örgütsel destek ve örgütsel bağhllk: Örgüt kaynaklı özsaygi'nn düzenleyici rolü. Yayımlanmamış Yüksek Lisans Tezi. Yeditepe Üniversitesi, Sosyal Bilimler Enstitüsü, İstanbul.

Wittekind, A., Raeder, S. ve Grote, G. (2009); A longitudinal study of determinants of perceived employability. Journal of Organizational Behavior, 31(4), 566586.

Yeşiltaş, M., (2014). Kurumsal sosyal sorumluluk algısının örgüt temellï öz saygya etkisinde algilanan örgütsel prestijin araclık rolü. Gazi Üniversitesi İktisadi ve İdari Bilimler Fakültesi Dergisi, 16(1), 118-144.

Yıldırım, F. (2003). Çalışma yaşamında örgüte bağlılık ile örgütsel adalet, örgüt temelli özsaygı ve bazı kişisel ve örgütsel değişkenlerin ilişkisi. Mülkiye Dergisi, 27( 239), 371-402. 
Ek-1 Örgüt Temelli Özsaygı ve Algılanan İstihdam Edilebilirlik Kavramlarına Dayalı Olarak Oluşturulan Anket Formu

\begin{tabular}{|c|c|c|c|c|c|c|}
\hline Cinsiyetiniz nedir? & (2) Kadın & \multicolumn{5}{|c|}{ (2) Kadın } \\
\hline Statü & (1)Öğretim Üyesi & \multicolumn{2}{|c|}{ (2)Öğretim Görevlisi } & \multicolumn{3}{|c|}{$\begin{array}{l}\text { (3) Araştırma } \\
\text { Görevlisi }\end{array}$} \\
\hline Kaç yaşındasınız? & $\begin{array}{l}\text { (1) } 20 \text { ve altı } \\
\text { (4) } 61 \text { ve üstü }\end{array}$ & \multicolumn{2}{|c|}{ (2) $21-40$} & \multicolumn{3}{|c|}{ (3) $41-60$} \\
\hline Öğrenim durumunuz nedir? & (2)Yüksek Lisa & \multicolumn{2}{|c|}{ (2)Yüksek Lisans } & \multicolumn{3}{|c|}{ (3)Doktora } \\
\hline & & 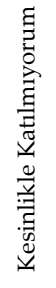 & 혈 & 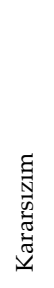 & 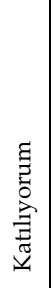 & 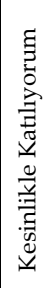 \\
\hline \multicolumn{7}{|l|}{ Örgüt Temelli Özsaygı Ölçeği } \\
\hline 1.Yararlıyım. & & (1) & (2) & (3) & (4) & (5) \\
\hline 2.Verimliyim. & & (1) & (2) & (3) & (4) & (5) \\
\hline 3.Uyumluyum. & & (1) & (2) & (3) & (4) & (5) \\
\hline 4.Güveniliyorum. & & (1) & (2) & (3) & (4) & (5) \\
\hline 5.İnaniliyorum. & & (1) & (2) & (3) & (4) & (5) \\
\hline 6.Fark yaratabiliyorum. & & (1) & (2) & (3) & (4) & (5) \\
\hline 7.Değerliyim. & & (1) & (2) & (3) & (4) & (5) \\
\hline 8.Sözüm geçiyor. & & (1) & (2) & (3) & (4) & (5) \\
\hline 9.Ciddiye alınıyorum. & & (1) & (2) & (3) & (4) & (5) \\
\hline 10.Önemliyim. & & (1) & (2) & (3) & (4) & (5) \\
\hline \multicolumn{7}{|c|}{ Algılanan İstihdam Edilebilirlik Ölçeği } \\
\hline \multicolumn{2}{|c|}{ 1.Bu işletmede sahip olduğum ilişkiler kariyerimde yardımcı olur. } & (1) & (2) & (3) & (4) & (5) \\
\hline \multicolumn{2}{|c|}{$\begin{array}{l}\text { 2.Şu anki işimde kazanmış olduğum beceriler, bunun dışındaki diğer meslek alanlarına } \\
\text { da transfer edilebilir. }\end{array}$} & (1) & (2) & (3) & (4) & (5) \\
\hline \multicolumn{2}{|c|}{ 3.Başka işletmelerde de istihdam edilebilir olmak adına kendi kendimi geliştirebilirim. } & (1) & (2) & (3) & (4) & (5) \\
\hline \multicolumn{2}{|c|}{ 4.Mesleki ağlarımı ve iş bağlantılarımı kariyerimi geliştirmek için kullanabilirim. } & (1) & (2) & (3) & (4) & (5) \\
\hline \multicolumn{2}{|c|}{$\begin{array}{l}\text { 5.Eğer ihtiyacım olursa benzer bir işletmede şu anki işime benzer bir işi kolayca bula- } \\
\text { bilirim. }\end{array}$} & (1) & (2) & (3) & (4) & (5) \\
\hline \multicolumn{2}{|c|}{$\begin{array}{l}\text { 6.Şu an çalışmakta olduğum işletmeye benzeyen diğer işletmelerde benim gibi iş yapan } \\
\text { insanlar gerçekten talep görür. }\end{array}$} & (1) & (2) & (3) & (4) & (5) \\
\hline \multicolumn{2}{|c|}{ 7.Hemen hemen her işletmede benimkine benzer bir işe kolaylıkla girebilirim. } & (1) & (2) & (3) & (4) & (5) \\
\hline \multicolumn{2}{|c|}{$\begin{array}{l}\text { 8.Benimle benzer niteliklere sahip (bilgi, beceri, tecrübe v.s.) herhangi bir kişi, işverenler } \\
\text { tarafindan oldukça talep görür. }\end{array}$} & (1) & (2) & (3) & (4) & (5) \\
\hline \multicolumn{2}{|c|}{ 9.Becerilerim ve deneyimlerimle ilgili olan her işe girebilirim. } & (1) & (2) & (3) & (4) & (5) \\
\hline \multicolumn{2}{|c|}{$\begin{array}{l}\text { 10.Benimle benzer deneyime sahip insanlar, hem kendi işletmelerinde hem de } \\
\text { sektördeki diğer işletmelerde oldukça değer görür. }\end{array}$} & (1) & (2) & (3) & (4) & (5) \\
\hline \multicolumn{7}{|c|}{ Not: Ankete eklemek istediğiniz düşüncelerini lütfen burada belirtiniz. } \\
\hline
\end{tabular}




\section{Kaynakça Bilgisi / Citation Information}

Orçanlı, K. (2020). Örgüt temelli özsaygı ile algılanan istihdam edilebilirlik arasındaki ilişkide cinsiyetin düzenleyici etkisi ve bir uygulama. OPUS-Uluslararası Toplum Araştırmaları Dergisi, 15(10. Y1l Özel Sayıs1), 4781-4815. DOI: 10.26466/opus.706649 